TAPROBANICA, ISSN 1800-427X. October, 2010. Vol. 02, No. 02: pp. 72-85, 4 pls.

(C) Taprobanica Nature Conservation Society, 146, Kendalanda, Homagama, Sri Lanka.

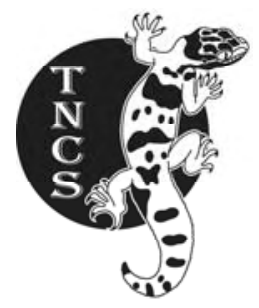

\title{
HERPETOFAUNA OF SOUTHERN WESTERN GHATS, INDIA - REINVESTIGATED AFTER DECADES
}

S. R. Chandramouli ${ }^{1}$ and S. R. Ganesh ${ }^{2}$

\footnotetext{
${ }^{1}$ Department of Zoology, Division of Wildlife Biology, A.V.C College, Mannampandal, Mayiladuthurai-609 305 , Tamil Nadu, India; E-mail: findthesnakeman@gmail.com

${ }^{2}$ Chennai Snake Park, Rajbhavan post, Chennai - 600 020, Tamil Nadu, India
}

\begin{abstract}
We recorded amphibians and reptiles in two hill ranges, the Cardamom Hills and Ponmudi Hills of the southern Western Ghats, India, for a period of four months each. In all, 74 species, comprising of 28 species of amphibians belonging to 11 genera and 8 families and 46 species of reptiles, belonging to 27 genera and 9 families were recorded. Aspects deviating from literature have been discussed. A comparison of the results of the present study with that of the earlier works from the same region is also provided.
\end{abstract}

Key words: Amphibians, Reptiles, Cardamom hills, Ponmudi hills, Reinvestigation, Herpetology

\section{Introduction}

The Western Ghats is one of the global biodiversity hotspots (Myers et al., 2000) and its herpetofauna has been investigated by several authors (Ferguson, 1895, 1904; Hutton, 1949; Hutton \& David, 2009; Inger et al., 1984; Ishwar et al., 2001; Kumar et al., 2001; Malhotra \& Davis, 1991; Vasudevan et al., 2001; Wall, 1919, 1920). These reports have provided details about diversity, distribution patterns and ecology of this community in these hill ranges. Since most of these works are decades old, we take the opportunity of presenting our recent investigations' results with photographic vouchers along with basic taxonomic and ecological data.

\section{Materials and Methods}

This work is based on an eight-month-long Visual Encounter survey (Campbell \& Christman, 1982) in post-monsoon season of two consecutive yeartransitions in two hill ranges (Map 1). Fieldwork was carried out in the Cardamom Hills, Theni and Virudunagar districts, Tamil Nadu state (Site 1; 09²5'- 09 $38^{\circ} \mathrm{N}, 7^{\circ} 21^{\prime}-77^{\circ} 34^{\prime} \mathrm{E}$; 500-1600 m asl.) by SRG during December 2007-March 2008; in the Ponmudi Hills, Thiruvananthapuram district,

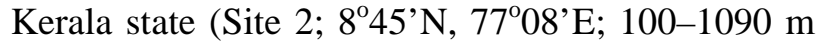
asl.) by SRC during December 2008-March 2009 for a duration of about four hours per day. Habitat types surveyed were moist deciduous, evergreen 
and montane forests as well as coffee, cardamom, rubber and tea plantations. Elevation in meters above sea level and geographic coordinates were determined using a Garmin-72, twelve channel Global Positioning System. Animals sighted in the wild were examined, photographed in-situ and released. Measurements in millimeters were recorded using a measuring tape and vernier calipers. Scale counts and associated morphological details were noted using magnifying hand lenses. Morphological examination methods followed Dutta \& Manamendra-Arachchi (1996) and Dubois \& Bour (2010) for amphibians and Smith $(1935,1943)$ for reptiles, except for ventral counts of snakes, for which we followed Dowling (1951) in the case of caenophidians Gower \& Ablett (2006) for anilioid snakes. Higher taxonomic nomenclature follows Dubois (2004) for amphibians and Carroll (1988) for reptiles. Abbreviations used for metric characters are, SVL (snout to vent length), TL (total length), tL (tail length). Amphibian larvae were staged following Gosner (1960). Our photographic vouchers are deposited with the India's Centre for Herpetology/ the Madras Crocodile Bank.

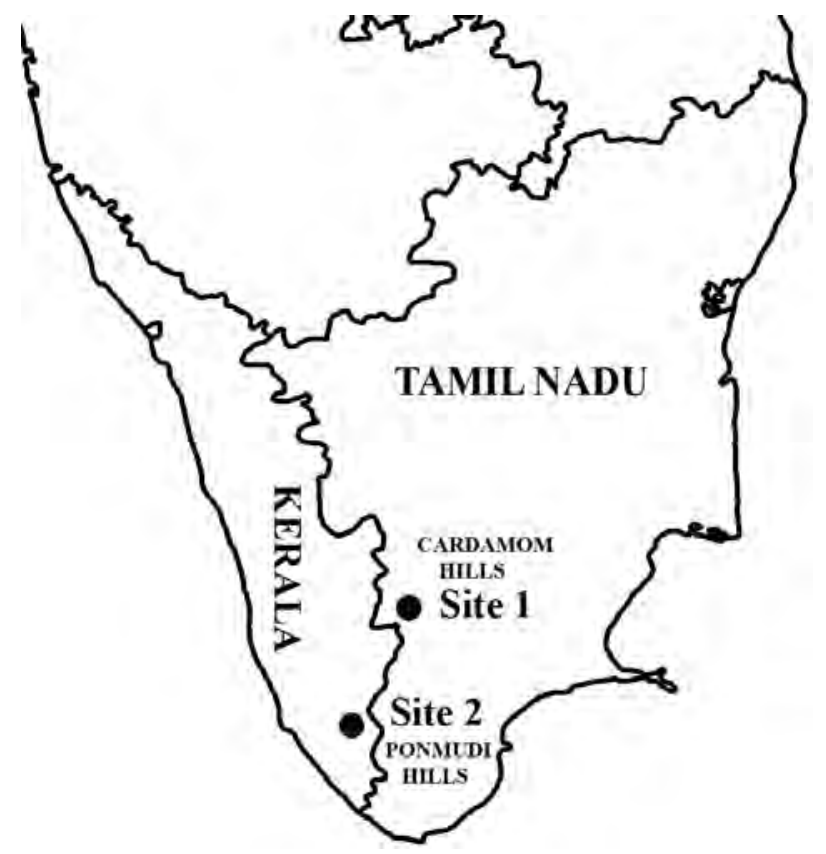

Map 1: Study sites

\section{Species Accounts}

Amphibia De Blainville, 1816 (Plate 1) Gymnophiona Rafinesque-Schmaltz, 1814

Ichthyophiidae Taylor, 1968

Ichthyophis beddomei Peters, 1879

Site 2: One adult (SVL $199 \mathrm{~mm}$; tL $4 \mathrm{~mm}$ ); crossing a road amidst human habitations at $107 \mathrm{~m}$ alt.

\section{Anura Duméril, 1805 \\ Bufonidae Gray, 1825}

\section{Bufo melanostictus (Schneider, 1799)}

Site 1: Many specimens were sighted on leaf litter, behind logs and rocks in human habitation. The largest specimen measured 211mm SVL. Juveniles, tadpoles of Gosner stages 36-39 and developing larvae were seen in temporary pools in low elevations.

\section{Bufo microtympanum (Boulenger, 1882)}

Site 1: Two adults (SVL 50, $55 \mathrm{~mm}$ ) from under small (ca. $0.3 \mathrm{~m}$ across) rocks in a path bordering tea and cardamom plantation, on a steep hill-side at elevations 1180 and $1570 \mathrm{~m}$.

\section{Bufo parietalis (Boulenger, 1882)}

Site 1: Several adults, (> $60 \mathrm{~mm}$ SVL) of which most $(n=18)$ were near streams in montane forest and the rest were on leaf litter in a cardamom plantation, at $1187-1372 \mathrm{~m}$ altitude.

Site 2: Two adults in evergreen forest near stream on leaf litter at 230-375 m altitude.

\section{Microhylidae Günther, 1858}

\section{Ramanella sp. (Fig. 1)}

Site 1: One specimen beneath a small $(30 \mathrm{~cm}$ across) rock in a torrential hill-stream running on barren rock-cliff edge of a hill top, heavy with mist and large patches of montane forests and tea plantations at $1500 \mathrm{~m}$ asl. Superficially resembles the Sri Lankan endemic R. obscura.

Diagnosis: Dorsum smooth with feeble traces of granules near limb insertions; a large, dark brown dorsal patch flanked by orangish yellow, which is absent in $R$. montana, $R$. mormorata and $R$. triangularis; palmar and plantar tubercles distinct, pale white; webbing in $4^{\text {th }}$ toe not exceeding penultimate subarticular tubercle; digits end with slightly rounded pads with no evident circummarginal groove.

Comments: $R$. obscura is a species endemic to south western Sri Lanka (Dutta \& ManamendraArachchi, 1996) and although Satyamurti (1967) referred a specimen originally labeled as $R$. obscura from south Coorg, Karnataka, India as R. montana, this specimen is not $R$. obscura but most likely represents an undescribed taxon (Kelum Manamendra-Arachchi, Madhava Meegaskumbura and Rohan Pethiyagoda, pers. comm., 2010). 


\section{Rhacophoridae Hoffman, 1932}

\section{Raorchestes akroparallagi (Biju \& Bossuyt, 2009)} (Fig. 2)

Site 2: One adult from evergreen forest close to stream on a rock, at $720 \mathrm{~m}$.

Comments: Probably, this species was referred to as Philautus femoralis by Inger et al., (1984) which is now considered to be restricted to the higher hills of Sri Lanka (Manamendra-Arachchi \& Pethiagoda, 2005). Also, it differs from $R$. bobingeri described by Biju and Bossuyt (2005) from the same locality in having a smooth dorsum (vs. granular in bobingeri). However, there is a controversy between Inger et al. (1984) and Biju \& Bossuyt (2005) regarding the skin texture of the specimens as the former state that " $P$. femoralis" (FMNH 218114) had a smooth dorsum while the latter mention it (as $P$. bobingeri) to be granular in texture.

Raorchestes anili (Biju \& Bossuyt, 2006) (Fig. 3)

Site 2: Three individuals were recorded between 542-760 m elevation. All were on rocks near streams.

Raorchestes beddomii (Günther, 1876) (Fig. 4)

Site 1: Five specimens on walls of the forest rest house at a height of about $2 \mathrm{~m}$, in the High Wavys, at $1510 \mathrm{~m}$ during late December. One adult on a cardamom plant, at a height of $1.2 \mathrm{~m}$, during late March.

Comments: A human commensally species, as all of them were seen in human habitations. Referred as Philautus pulcherrimus sensu Daniels (2005) in Ganesh et al. (2008a).

\section{Raorchestes charius (Rao, 1937)}

Site 1: Four individuals were recorded at an elevation of $1500 \mathrm{~m}$ on the ground in a cardamom plantation and montane forests, during early January and one subadult during late March, under the bark of a tree at a height of $1.2 \mathrm{~m}$ near a forest stream in montane forests bordering tea plantations.

\section{Raorchestes ponmudi (Biju \& Bossuyt, 2005)}

Site 1: Two adults of SVL $35 \mathrm{~mm}$, beneath fallen logs, on a forest path in a montane forest during late December. One near a stream with dense growth of ferns (Cyathea sp.) flowing through patches of montane forests near tea plantations.

Comments: Referred as Philautus variabilis sensu Daniels (2005) in Ganesh et al. (2008a).
Raorchestes cf. bobingeri (Fig. 5)

Site 1: One specimen under a fallen log behind tea bushes, in a patch of tea plantation and surrounding montane forests in Eravangalar, at $1483 \mathrm{~m}$ asl.

Diagnosis: Dorsum uniformly granular, olivaceous green; axilla, groin and parts surrounding limb insertions yellowish; canthus rostralis sharp; head broader than long; eye diameter equal to snout length; tympanum and supratympanic fold indistinct; webbing in toes extensive. This individual differs from the nominate taxa in having a greenish yellow femur (vs. reddish yellow in $P$. bobingeri fide Biju and Bossuyt, 2009).

Comments: Referred as Philautus pulcherrimus sensu Daniels (2005) in Ganesh et al. (2008a).

\section{Raorchestes cf. travancoricus (Fig. 6)}

Site 1: One adult (20 mm SVL) on a grassy meadow, in human habitations bordering a watershed catchment, near tea plantations and montane forest at an elevation of $1450 \mathrm{~m}$ during late January.

Philautus sensu lato sp. 1 (Fig. 7)

Site 2: Four individuals were seen in evergreen forests, two on rocks, near stream/s and two from leaf litter at elevations between 370 and $850 \mathrm{~m}$.

Diagnosis: Bright creamy brown dorsally, with a faint inter-orbital streak; lateral region, thigh and shank spotted with dark brown; toes partially webbed $\left(1 / 4^{\text {th }}\right)$; head as broad as long, tibio-tarsal articulation reaches the eye, canthus rostralis sharp, tympanum much smaller than the eye, snout length $4 \mathrm{~mm}$, eye diameter $3 \mathrm{~mm}$.

Comments: Biju et al. (2010) remarked Philautus Gistel, 1848, present in the Western Ghats to comprise of two, genetically distinct lineages, which they recognized as genera Raorchestes Biju, Shouche, Dubois, Dutta \& Bossuyt, 2010 and Pseudophilautus Laurent, 1943. Since these two genera are morphologically conservative, cryptic and not allopatric, we use the older concept of Philautus [in a glorified sense] for our unidentified individuals, which definitely do not belong to other rhacophorid genera of the Western Ghats.

Superficially resembles Raorchestes signatus sensu Inger et al. (1984). Raorchestes signatus s str. is a taxon restricted to the higher hills of Nilgiris (Biju \& Bossuyt, 2009). Biju \& Bossuyt (2009) refer Inger's $R$. signatus (FMNH 218118) as R.graminirupes (fide Biju \& Bossuyt, 2005). The present individuals differ from $P$. graminirupes described from the same locality, in possessing a smooth dorsum and an evidently longer snout (vs. 
granular dorsum and shorter snout than the eye diameter in $R$. graminirupes) [snout length: eye diameter ratio 1.33:1 in Philautus s. lat. sp. 1 vs. 0.77:1 in R. graminirupes] fide Biju and Bossuyt (2005). Also, it differs from $P$. chotta in comparatively larger size (SVL $23.5 \pm 2.12 \mathrm{~mm}$ $[\mathrm{n}=4]$ vs. $<20.5 \mathrm{~mm}$ in $P$. chotta).

\section{Philautus sensu lato sp. 2 (Fig. 8)}

Site 2: One individual from a forest stream on rock, at $542 \mathrm{~m}$.

Diagnosis: Dorsum moderately pustular; canthus rostralis sharp; tympanum smaller than eye; supratympanic fold evident. Colour, dorsally deep reddish brown, temporal and labial region with dark brown; 'inverted $\mathrm{V}$ ' mark on back; hindlimbs barred.

Comments: This specimen was only photographed and could not be restrained for examination.

\section{Rhacophorus malabaricus Jerdon, 1870}

Site 2: One adult female, on a shrub at $1.5 \mathrm{~m}$ height, near its nest, which was made of leaves stuck together with foam, about $2 \mathrm{~m}$ above a stagnant pool at elevation of $720 \mathrm{~m}$.

\section{Micrixalidae Dubois, Ohler \& Biju, 2001}

\section{Micrixalus fuscus (Boulenger, 1882)}

Site 1: Very common; many were recorded from large water courses ( $>3 \mathrm{~m}$. wide) to small hill torrents, bordering plantations and three away from streams.

Site 2: Many were recorded from streams from 370-1018 m altitudinal range. Intra-specific tolerance high; stenotopic and dominant in torrential settings, never syntopic with lentic-water-dwelling anurans. They called from rocks, in streams, small shrubs, mostly ferns and other vegetation, ascending up to $60 \mathrm{~cm}$ to gain vantage point and bred during erratic, non seasonal rains in January-March, as tadpoles of Gosner stage 36-39 were seen.

\section{Micrixalus nudis Pillai, 1978}

Site 2: Five individuals were seen near streams, on rocks and leaf litter within 370-1018 m asl.

\section{Dicroglossidae Anderson, 1871}

\section{Fejervarya keralensis (Dubois, 1980)}

Site 1: One specimen in montane forest, near a stream at $1450 \mathrm{~m}$. Some tadpoles of Gosner stage 36, though observed could not be attributed to this species, as Micrixalus was also found together. Eight specimens from streams in mid elevation
700-1000 m. Adults occupied both lentic and lotic waters.

Site 2: Four adults from forest streams within156$830 \mathrm{~m}$ altitude.

\section{Fejervarya limnocharis complex sensu Kuramoto et al., (2007)}

Site 1: Thirteen individuals were seen in moist deciduous forests at 500-700 m. Adults, juveniles, and tadpoles of Gosner stages 36-39 in pools near forest clearings and wallows used by large ungulates.

Diagnosis: Dorsum pustular with numerous warts; eyes protruding, iris fawn-brown; pupil black, diamond-shaped; snout pointed, nostril oriented towards the upper aspect of snout; not close to the snout-tip; canthals mildly evident; supratympanic fold prominent; head very large and broad; trunk short, thick, hind limbs moderately long; tibio-tarsal articulation reaches nostril or snout-tip; webbing of toes up to $3 / 4^{\text {th }}$; digits not dilated into discs, rather convergent and slender; $4^{\text {th }}$ toe longest. Colouration, dorsally dirty brown with random marblings of darker shade, a bright yellow vertebral stripe, extending from interorbital to groin, frequently present; venter smooth, white, darker near gular region and limb insertions. SVL $\leq 34 \mathrm{~mm}$.

Comments: "Fejervarya limnocharis" is a speciescomplex (Kuramoto et al., 2007).

\section{Ranidae Rafinesque, 1814}

\section{Sylvirana aurantiaca (Boulenger, 1904)}

Site 2: Seven individuals were seen along stream sides at $376 \mathrm{~m}$ asl.

Comments: Curiously this species wasn't reported by Inger et al. (1984) from Ponmudi (Site 2) which is ca. $60 \mathrm{~km}$ northeast from its type locality, Trivendrum (now Thiruvanathapuram).

\section{Sylvirana temporalis (Günther, 1864) sensu Dutta} (1997)

Site 1: Four adults (> $60 \mathrm{~mm} \mathrm{SVL}$ ) from streams, in montane forests and tea plantations at $1450 \mathrm{~m}$ asl. during December- January. Nine adults from deciduous forests at 600-1250 $\mathrm{m}$ asl. during February-March. A mounted pair in amplexus perched on exposed roots of nearby plants along a stagnant water body at $900 \mathrm{~m}$ asl. was seen during mid day; sympatric with Hydrophylax malabarica.

Site 2: Five adult frogs were recorded from rocks near streams and leaf litter in mid-elevation evergreen forests, within 565-910 m asl. 
Hydrophylax malabaricus (Tschudi, 1838)

Site 1: Two specimens in a stream on eastern slopes at $1300 \mathrm{~m}$ asl during early January. Nine adults, most $(n=7)$ from evergreen forests, interspersed with rocky cliffs and vast grassland, at $1300 \mathrm{~m}$ asl during late January. Associated with large, deep waters, often sympatric with Sylvirana temporalis sensu Dutta (1997).

\section{Petropedetidae Noble, 1931}

\section{Indirana beddomei (Günther, 1875)}

Site 1: Several individuals; mostly near streams, on rocks, leaf litter, under logs, stones and on bare ground, in moist deciduous forests, evergreen rain forests, montane forests, cardamom and coffee plantations. Eurytopic with a wide elevation range of 500-1500 m. Males called and bred in small streams in evergreen forests at February-March, during rains.

Site 2: Several adults were sighted on leaf litter away from streams in forest patches. Altitudinal distribution was extensive, with the majority between 370-650 $\mathrm{m}$ asl.

\section{Indirana brachytarsus (Günther, 1875)}

Site 2: Seven adults were seen along stream sides and on leaf litter from altitudes 360-670 m.

\section{Indirana semipalmata (Boulenger, 1882)}

Site 1: Eleven specimens from streams near tea plantations, and in lower altitudes of 800-1000 m during February-March, often sympatric with $I$. beddomei and I. leptodactylus in streamside forests and riparian vegetation, but less numerous or absent in altered habitats.

\section{Indirana leptodactyla (Boulenger, 1882)}

Site 1: Many specimens; mostly seen near streams and sometimes in non riparian habitats. Often sympatric with $I$. beddomei and once these two species bred in a same shallow pool during erratic rains (i.e. February-March) far from south-west monsoon. Foamy nest masses, together with $I$. leptodactylus and I. beddomei adults were observed at 700-900 $\mathrm{m}$ asl.

\section{Indirana cf. diplosticta}

Site 1: Three specimens in stream-sides, on rocks, bare cliff-faces and in clumps of mountain grass, during late January.

Diagnosis: Superficially similar to I. diplostictus, but larger (> $45 \mathrm{~mm} \mathrm{SVL}$ ) and much darker, almost grayish black. Colouration grayish red above; skin with longitudinal folds; tympanum diameter half that of the eye; supratympanic ridge evident; canthus rostralis sharp; limbs barred; digits with dilated discs; circummarginal grooves mildly evident; webbing in pes $3 / 4^{\text {th }}$.

Comments: Though I. diplostictus was previously recorded from these hills (Daniels, 2005) our specimens did not completely match with $I$. diplostictus.

\section{Nyctibatrachidae Blommers-Schlösser, 1993}

\section{Nyctibatrachus major Boulenger, 1882}

Site 1: One adult from a stream near tea plantations, at $1500 \mathrm{~m}$ during late March. Four adults from stream sides and riparian tracts at $800-1000 \mathrm{~m}$. During late February an egg mass with 24 embryos visible inside the eggs spread $51 \mathrm{~mm}$ across was seen deposited on a rock $6 \mathrm{~cm}$ high overseeing an intermittent stream, with an adult nearby.

Site 2: Eleven adults were seen near streams in evergreen forests, never away from water bodies, at an altitudinal range of $350-800 \mathrm{~m}$; even close to human habitations, near waterways flowing past roads.

\section{Reptilia Laurenti, 1768 Squamata Oppel, 1811 Sauria Gunther, 1984 (Plate 2) \\ Gekkonidae Gray, 1825}

\section{Cnemaspis beddomei (Theobald, 1876)}

Site 1: Nine specimens, with most $(n=7)$ from human settlements often resting on open bare walls during night and a few $(n=2)$ from natural forest habitat, in rock cut cave formations, tree buttresses and under fallen logs in forest floor. Sympatric with C. nairi.

Comments: Misidentified as Cnemaspis indica in Ganesh et al. (2008a).

\section{Cnemaspis nairi Inger, Marx \& Koshy, 1984}

Site 1: Many specimens, most $(\mathrm{n}=16)$ from human settlements, a few $(n=5)$ from forests, mainly in higher elevation forests $>1200 \mathrm{~m}$ including a gravid female with two developing ova, seen under a fallen $\log$ in a riverine forest tract of Sithathu kavu at 1200 $\mathrm{m}$. Several eggs were seen in cave formations, along with adults of this species in the vicinity, the largest such cluster composed of 24 eggs, of which 14 had already hatched, during late January.

Comments: This species was not recorded in Site 2, its type locality 
Cnemaspis ornata (Beddome, 1870)

Site 1: Nineteen individuals, often from lower elevation forests in rock formations and caves in the foothills of Ayyanar koil, two from mid elevation (800-1000 m) including a gravid female, with two developing ova, under a stone, in a riverine tract. Site 2: One adult female from a rock crevice in a tea estate at $670 \mathrm{~m}$ asl.

\section{Cnemaspis sp. (Fig. 9)}

Site 1: One specimen, a gravid female, with two developing eggs inside, from cardamom plantations during late December.

Site 2: One adult male measuring $30 \mathrm{~mm} \mathrm{SVL}$, tL $38 \mathrm{~mm}$, from deciduous forest at $1000 \mathrm{~m}$ elevation.

Diagnosis: Dorsum somewhat smooth; conical spine-like tubercles present on flanks and tail, supralabials 8 , head length twice the breadth; $4^{\text {th }}$ toe subdigitals 6. Overall habitus and lepidosis resembled $C$. mysoriensis-nilagirica complex but with smooth venter (vs. keeled) and a black gular region (vs. yellowish with black reticulations).

\section{Hemidactylus anamallensis (Günther, 1875)}

(Fig. 10)

Site 1: Twenty one adults (SVL 55-76 mm) sympatric with Cnemaspis nairi and C. beddomei on walls, window panes and ceilings of an estate bungalow in Kottai malai at $1200 \mathrm{~m}$ asl.

\section{Hemidactylus maculatus (Duméril \& Bibron, 1836) sensu Smith (1935)}

Site 1: Eleven specimens, two from a root tangle of a large tree buttress, near the foothills of Ayyanar koil (500 m asl); in mid hills of Kottai malai (630 m asl), on a rock formation and the rest $(n=6)$ from walls of a forest rest room in Mudaliar ootru (1300 $\mathrm{m}$ asl) at a height of above $1.8 \mathrm{~m}$. from ground.

Hemidactylus parvimaculatus Deraniyagala, 1953

Site 2: One gravid specimen bearing 2 eggs, from a cottage in Merchiston Estate at $670 \mathrm{~m}$. Sympatric with Gehyra mutilata.

Comments: Bauer et al. (2010) reported genetic divergence in $H$. brookii and further raised the subspecies parvimaculatus to full species. It is a chiefly Sri Lankan clade that is also distributed in the Maldives and Kerala, southwestern India.

Hemidactylus frenatus Duméril \& Bibron, 1836

Site 2: Two adult females from secondary vegetation near plantations on a shrub and rocks at $830 \mathrm{~m}$.
Gehyra mutilata (Wiegmann, 1834) (fig. 11)

Site 2: Nine specimens, including two juveniles and a gravid female (SVL $63 \mathrm{~mm}$ ) bearing two eggs were recorded from houses and other constructions in Merchiston Estate, at $675 \mathrm{~m}$ asl.

Comments: This species, though relatively common in this hill range, was not reported by Inger et al. (1984). Smith (1935) states that "the only authentic record for this species from the Indian peninsula is a specimen from Cochin, in the Indian Museum” while Das (2002) gives its distribution in southern India as Kerala. The present record from Ponmudi provides a precise distribution locality for this species in Kerala, where it is relatively common.

\section{Agamidae Gray, 1827}

\section{Draco dussumieri Duméril \& Bibron, 1837}

Site 1: Eighteen specimens, most $(\mathrm{n}=14)$ from moist deciduous and disturbed gallery forests, in areas with large, mature trees in plenty, perched at heights between 1 and $8 \mathrm{~m}$, in Ayyanar koil at $500 \mathrm{~m}$ asl. during late January. Four on drier, sparsely vegetated, rocky eastern slopes of Mudaliar ootru at $800 \mathrm{~m}$.

Site 2: Two adults, a male and a female were sighted on tree trunk at a height of about $2.1 \mathrm{~m}$ above the ground at $470 \mathrm{~m}$.

\section{Otocryptis beddomii Boulenger, 1885}

Site 2: Several individuals were sighted on leaf litter, ground vegetation and shrubs. Comments: Distributed widely from 110 - 1018 m asl., as opposed to $\leq 650 \mathrm{~m}$ asl fide Inger et al. (1984) see Chandramouli (2009a).

\section{Calotes calotes (Linnaeus, 1758)}

Site 1: Seven adult males, 3 unsexed subadults and juveniles from moist deciduous forests with poor canopy cover perched at heights 1-2.5 m; in Ayyanar koil (500-800 m), Periya kavu (700-900 $\mathrm{m})$ and in the mid hills of Kottai malai $(<700 \mathrm{~m})$.

Site 2: Two adult females and four subadults were recorded from deciduous forests and tea plantations, on shrubs and on the ground at elevations between 110 and $836 \mathrm{~m}$.

\section{Calotes elliotti Günther, 1864}

Site 1: Twenty eight specimens from higher altitudes at $1300-1600 \mathrm{~m}$ asl. in montane forests $(n=9)$, tea $(n=8)$ and cardamom $(n=11)$ plantations, often in areas with no or poor canopy cover, with often quite low perching heights, up to $<0.3 \mathrm{~m}$., but most $(n=11)$ perched at $1-1.8 \mathrm{~m}$ height; several seen sleeping on barbed wires, lamp posts and window 
panes. Eurytopic, human commensal in high altitude zones.

Site 2: Five individuals were recorded from elevation from 376 to $800 \mathrm{~m}$. Three adults were on shrubs perched at $1.3-1.8 \mathrm{~m}$ height and two juveniles were seen on the ground among leaf litter.

Comments: Inger et al. (1984) considered C. elliotti to be synonymous with $C$. rouxii and referred their animals as $C$. rouxii, although the specific status of C. elliotti has been accepted universally (e.g., Smith, 1935; Das, 2002). We did not see any $C$. rouxii sensu stricto in Sites 1 and 2.

\section{Calotes grandisquamis Günther, 1875 (Fig. 12)}

Site 1: Ten adults from tea and cardamom plantations of High Wavys ( $\mathrm{n}=6$ ) at $1450 \mathrm{~m}$ asl., one seen sleeping on Lantana camara bush at $1.2 \mathrm{~m}$ height and a road-kill on a path bordering tea plantations. A pair in a cardamom plantation, male perched at a height of $1.2 \mathrm{~m}$ and female at $2 \mathrm{~m}$ in Periya kavu $(n=2)$ and Kottai malai $(n=2)$ plantations. In Kottai malai (1180 m asl) a female scratched the ground to make a hole-nest that was a hemispherical depression measuring $43 \mathrm{~mm}$ diameter and $40 \mathrm{~mm}$ depth, in the middle of a footpath at $15.20 \mathrm{hrs}$.

Site 2: A single adult female measuring SVL 124 $\mathrm{mm}$, tL $311 \mathrm{~mm}$ was seen in a rubber plantation at $107 \mathrm{~m}$, amidst human habitation. This specimen was an aberrant morph, in having a bright green dorsum with white transverse bars.

Comments: Not reported by Inger et al. (1984) from Site 2. The aberrant specimen from Site 2 was discussed at length by Chandramouli (2009b).

\section{Psammophilus dorsalis (Gray, 1831)}

Site 1: Six specimens; adult male $(\mathrm{n}=1)$, females $(n=3)$ and unsexed subadults $(n=2)$ from rocky open bare patches in hill slopes, irrespective of altitude but mostly at $500-1300 \mathrm{~m}$.

Site 2: Twelve adults were sighted on rocks at hill tops from altitudes varying between 700-1090 m.

Comments: Inger et al. (1984) reported $P$. blandfordanus from this region (Site 2), which was not encountered in this study.

\section{Scincidae Gray, 1825}

\section{Eutropis carinata (Schneider, 1799)}

Site 1: Twenty eight specimens, most $(n=13)$ in stone revetments bordering tea plantations, human settlements, cardamom plantations, montane forests, open clearings, shoal-grasslands of High Wavys at 1400-1600 m asl.
Site 2: Seven specimens were sighted among grassy thickets at higher altitudes $(>900 \mathrm{~m})$ and among human habitation and plantations in lower altitudes.

\section{Eutropis clivicola (Inger, Shaffer, Koshy \& Bakde, 1984) (Fig. 13a,b)}

Site 2: Three individuals were recorded from a rubber plantation at $107 \mathrm{~m}$. Dorsum bronze brown with three black longitudinal stripes, the dorsolateral ones from postocular region and the mid-dorsal stripe from the neck, behind the nuchals till the tail, venter pale white. Lateral region dark, with numerous white spots.

Comments: The third specimen reported here forms the record length (SVL $63 \mathrm{~mm}$; Tail $41 \mathrm{~mm}$ ) for this species (vs. SVL $55 \mathrm{~mm}$ in paratypes FMNH 216580 and 81) fide Inger et al., (1984); 30 scales round the mid-body vs. 28 reported by Inger et al. (1984) and Thomas and Easa (1997). Thus, the present record reports revised scale counts and longest length record for this species, with the lower altitudinal distribution range being extended from 260, 250 and $148 \mathrm{~m}$ (Inger et al., 1984; Thomas and Easa, 1997) to $107 \mathrm{~m}$.

\section{Eutropis macularia (Duméril \& Bibron, 1839)}

Site 1: Abundant, averaging 3-6 individuals a day, in low to mid hills at 500-1000 m, on leaf litter, ground vegetation, bare soil, rocks and fallen logs. Site 2: Very common; many were sighted on leaf litter at varying altitudes between 107-670 m. More terrestrial; they were usually seen on leaf litter, along the roadsides and rarely in human habitations. Almost half of our specimens had a scarlet red throat.

Eutropis cf. beddomei (Fig. 14)

Site 1: One specimen from near a wood-heap in cardamom plantation, High Wavys, at $1450 \mathrm{~m}$.

Diagnosis: Midbody scalerows $30 ; 4^{\text {th }}$ toe subdigitals 15; supranasals touching one another; loreal + presuboculars 4; postnasal absent; supraciliaries 5; only $2^{\text {nd }}$ supraocular contacting frontal; auricular lobules feeble; scales between circumorbitals and tympanum 7; dorsum with five stripes, more prominent anteriorly. Agreeing with $E$. beddomei, but varied in having higher degree of scale-carination, especially in lateral and temporal regions.

\section{Kaestlea laterimaculata (Boulenger, 1887)}

Site 1: Twelve specimens (2 adults and 10 juveniles), from high altitudes of 1450-1600 m, in tea and cardamom plantations, montane forests, open clearings and shola-grassland habitats. 
Kaestlea travancorica (Beddome, 1870)

Site 1: Five specimens (1 adult and 4 juveniles) from riverine forests of Sithathu kavu, at $1200 \mathrm{~m}$ and in montane forests, clearings and sholagrasslands of High Wavys at $1450 \mathrm{~m}$.

\section{Ristella guentheri Boulenger, 1887 (fig. 15)}

Site 1: Seven adults, most $(n=4)$ in dense montane forests, contiguous or fragmented, but always inside tree cover, in wet humus laden places like leaf litter or forest floor, under fallen logs, stones, rocks, tree buttress spaces and never in open places without canopy cover at $1450-1650 \mathrm{~m}$. Highly stenotopic. Site 2: An adult and a juvenile, from leaf litter in evergreen forest at altitudes of $680-935 \mathrm{~m}$.

Comments: Specimens from Site 1 were misidentified as Ristella travancorica in Ganesh et al. (2008a).

\section{Sphenomorphus dussumieri (Duméril \& Bibron, 1839)}

Site 2: Very common at elevations from $107-540$ $\mathrm{m}$; regularly seen on leaf litter and on rocks, especially near streams, where Eutropis spp. rarely occurred.

\section{Varanidae Gray, 1827}

\section{Varanus bengalensis (Daudin, 1802)}

Site 1: Three adults (>600 mm SVL). One was foraging in a rocky substratum of a river bed, in Ayyanar koil at $500 \mathrm{~m}$ during late January, another individual in human habitations, in Periya kavu, at $800 \mathrm{~m}$ during late February, the next individual was in a valley of riverine forest tract of Sithathu kavu, at $1250 \mathrm{~m}$.

\section{Serpentes Linnaeus, 1758 (Plate 3 \& 4) Uropeltidae Müller, 1832}

\section{Uropeltis arcticeps madurensis (Beddome, 1878)} sensu Whitaker \& Captain (2004)

Site 1: Four specimens; from montane forests, cardamom and tea plantations $(\mathrm{n}=1$, each) and one from human settlements in High Wavys at 1300 $1600 \mathrm{~m}$ during December-January. An adult (200 $\mathrm{mm}$ SVL) under a rock (0.7 $\mathrm{m}$ across $)$ in a streamside forest tract in Sithathu kavu, at $1250 \mathrm{~m}$ during January was observed to share the same log along with a Ristella guentheri as refuge. One, clearly identifiable, road-killed individual was sighted on a road across coffee plantations.

Comments: Smith (1943) synonymised Silybura madurensis Beddome, 1878 and Silybura arcticeps Günther, 1875 but yet recognized them as two "varieties", based on their non-overlapping ventral counts; U. a. arcticeps from Tinnevelly having 127128 ventrals and $U$. a. madurensis from Travancore having 146-157. Their subspecific status has been maintained (see Whitaker \& Captain 2004).

\section{Uropeltis cf. dindigalensis (Fig. 16)}

Site 1: Four adults, two dead and two live, one of which was observed to feed on an earthworm, on a foot path, in a cardamom plantation in a sun-lit patch, at broad day light of a noon, during late December. One live adult under a large fallen tree trunk, within a patch of montane forest, in Eravangalar Estate, High Wavys at 1550 m. Dead ones were on a tarred road, passing through tea plantations and montane forests. Another dead one was sighted in the same estate, allegedly killed by a domestic fowl.

Diagnosis: Superficially similar to $U$. dindigalensis but caudal disc, more like that of Group III of Smith (1943). Rostral fully dividing nasal scales and nearly equal to its distance from frontal; dorsum yellowish brown; laterally darker; venter dark purplish brown with distinct alternate yellow spots.

Comments: This species also resembles $U$. liura (David Gower pers. comm.). However the present individual with its rostral dividing nasal scale and touching the medial suture between prefrontals is in strong contrast to $U$. liura. But several $U$. liura specimens often have such a posteriorly elongated rostral shield (David Gower pers. comm.). Since, the condition of rostral and nasal scales are given as taxonomically important diagnostic characters by Smith (1943), we refer our individuals as Uropeltis cf. dindigalensis and not Uropeltis cf. liura.

\section{Pythonidae Fitzinger, 1826}

\section{Python molurus (Linnaeus, 1758)}

Site 1: One adult ( $>2100 \mathrm{~mm}$ TL), basking on a large rock near a river course, during forenoon in Sithathu kavu, a riverine tract at $1250 \mathrm{~m}$, during late January.

\section{Colubridae Oppel, 1811}

Coelognathus helena monticollaris (Schulz, 1992)

Site 1: One adult (SVL $590 \mathrm{~mm}$; TL $720 \mathrm{~mm}$ ) crossing a forest path, on a steep rocky hill slope with clumps of mountain grass and bare rocks and ferns; from Mudaliar ootru, an evergreen forest, at $1200 \mathrm{~m}$ during late January.

\section{Ptyas mucosa (Linnaeus, 1758)}

Site 1: Four adults, including a dead one in tea plantations of High Wavys, during early January, as 
well as in lower elevation (500-800 m) forests of Ayyanar koil in moist deciduous and evergreen forests during early February.

Site 2: Three adults were recorded from both forests and also along road sides at 380-500 m.

Oligodon venustus (Jerdon, 1853) (Fig. 17a,b,c)

Site 1: One adult (SVL $353 \mathrm{~mm}$, TL $410 \mathrm{~mm}$ ), moving through mountain grasses and ferns, near a disturbed bush patch of Lantana camara in shola grasslands of High Wavys at $1540 \mathrm{~m}$ during late March.

\section{Oligodon travancoricus Beddome, 1877 (Fig. 18a,b,c)}

Site 1: Four adults (two males and females each) from Periya kavu and Kottai malai Estates at 800 $1200 \mathrm{~m}$ in evergreen forests, cardamom plantations and nearby human habitation.

Comments: These specimens have been discussed elaborately in Ganesh et al. (2009). Although the specific distinction of this species has been considered doubtful (Wall, 1914), subsequent workers regarded it to be distinct from its closely allied sympatric congener $O$. venustus (Jerdon, 1853) (e.g., Smith, 1943; Molur \& Walker, 1998; Sharma, 2003; Whitaker, 1978; Whitaker \& Captain, 2004). Wall (1914) provided a comparison between $O$. travancoricus and $O$. venustus, in which, he mentioned the following differences; frontal shield shorter than parietals in $O$. travancoricus (vs. as long as the parietals in $O$. venustus), three infralabials touch the anterior chin shields (vs. four in contact with chin shields in $O$. venustus). Apart from these differences in scalation, they differ in colouration; i.e., dorsum barred in $O$. travancoricus (vs. medially united paired spots in O. venustus). Additionally Smith (1943) remarks, subcaudals with alternate black and white markings in O. travancoricus (vs. predominantly yellowish in venustus) and $6^{\text {th }}$ supralabial, which is completely in contact with labial border in O. travancoricus (vs. often excluded from the labial border in $O$. venustus) (see Figs. 18 \& 19). In addition, we observed another difference; viz., the posterior edge of the parietals are obtusely pointed in $O$. travancoricus, forming a groove in between vs. flat and truncate in $O$. venustus. Elsewhere, such minute variations in head scalation have been considered as vital characters of diagnostic importance to distinguish cryptic/ sibling species (Boulenger, 1894; Gower \& Winkler, 2007). Therefore, we accord with Smith (1943) and consider the taxa $O$. travancoricus and $O$. venustus to be specifically distinct.
Oligodon affinis Günther, 1862 (Fig. 19)

Site 2: One adult from evergreen forest on leaf litter, at $430 \mathrm{~m}$.

Lycodon travancoricus (Beddome, 1870) (Fig. 20)

Site 1: Six adults, from High Wavys at $1450 \mathrm{~m}$, during early January, a pair from inside an estate cottage; an exceptionally brightly marked specimen from under a stone near tea plantation in Eravangalar at $1550 \mathrm{~m}$; from under a dead-wood in Ayyanar koil at $500 \mathrm{~m}$, during early February; in coffee plantations of Periya kavu, at $800 \mathrm{~m}$.

Site 2: Two adults and one juvenile from 836, 675 and $110 \mathrm{~m}$. Adults were found among human habitation in tea plantations and the juvenile was seen crossing a road at night.

Comments: Whitaker \& Captain (2004) state "subcaudals paired or some (rarely all) entire", which is supported by our observation (see fig.).

\section{Dendrelaphis grandoculis (Boulenger, 1890) (Fig.} 21)

Site 2: Two adults on shrubs at a height of about $1.7-2.1 \mathrm{~m}$ from the ground, at $1018 \mathrm{~m}$.

Comments: Inger et al. (1984) did not report this species from Site 2 (Ponmudi), but it has been recorded from Kannikatti (700 m asl.), an adjacent forest patch in Kalakkad-Mundanthurai Tiger Reserve in Tamil Nadu, (fide Whitaker \& Captain, 2004) which is contiguous with Ponmudi.

\section{Xenochrophis piscator (Schneider, 1799) (fig. 22)}

Site 1: One adult from a streamside in Eravangalar, amidst tea estates at $1550 \mathrm{~m}$.

Site 2: One adult from a stream near human habitation at $107 \mathrm{~m}$.

Comments: Our specimens had 73 and 87 subcaudals and thus are female $X$. piscator sensu Vogel \& David, (2006).

\section{Amphiesma beddomei (Günther, 1864)}

Site 1: Two specimens, an adult (> $700 \mathrm{~mm}$ SVL) from cardamom plantations in High Wavys at 1400 $\mathrm{m}$ during early January and a juvenile in a small open stream in tea plantation at $1450 \mathrm{~m}$ during late March.

Site 2: Eight adults from evergreen forest on leaf litter, at elevations between $376-1018 \mathrm{~m}$.

Comments: An adult measuring $380 \mathrm{~mm}$ SVL, 495 mm TL, had 52 subcaudals (vs. 62 - 82 fide Smith, 1943 and Whitaker \& Captain, 2004).

\section{Macropisthodon plumbicolor (Cantor, 1839)}

Site 1: One subadult, with characteristic nuchal mark, from under a small rock (c.a. $0.3 \mathrm{~m}$ across) in 
a tea and silver oak plantation in High Wavys at $1550 \mathrm{~m}$ on a rainy day, in late December.

\section{Xylophis captaini Gower \& Winkler, 2007}

Site 2: One roadkill, adult, near a rubber plantation at $107 \mathrm{~m}$.

\section{Boiga ceylonensis (Günther, 1858)}

Site 1: One adult female coiled inside the bark of a tree trunk, overhanging a hill-stream, at a height of $1.2 \mathrm{~m}$ from ground during late March, near a tea plantation and montane forests of Eravangalar at 1450 m. Philautus spp. $(\mathrm{n}=4)$ were seen inside the same bark crevice.

Boiga nuchalis (Günther, 1875) (fig. 23)

Site 2: One adult from shrubs along roadside, at 670 $\mathrm{m}$.

\section{Ahaetulla dispar (Günther, 1864) (fig. 24)}

Site 1: Four specimens (three adults and one subadult), two from tea and one each from cardamom plantation and montane forest at a height of 1-1.2 m from ground and once on a forest path, on bare ground at 1450-1650 m.

\section{Ahaetulla nasuta (Lacépède, 1789) sensu Whitaker \& Captain (2004) (Fig. 25)}

Site 1: Two adults in lower and mid elevations of Ayyanar Koil and Sithathukavu at 600-1000 m. One specimen had a ventral pattern with two thin white stripes running along the entire body length. Site 2: Three individuals from shrubs and tea bushes in 260-700 m.

Comments: Colouration of our individuals accord with Whitaker \& Captain (2004), except that ventrals sometimes had two pale white parallel stripes, apart from ventrolateral stripes. Ventral pattern is highly variable in $A$. nasuta and has largely contributed to many of its 'varieties' and synonyms (Smith, 1943). We believe that these synonyms need to be carefully reevaluated, as the form called 'nasuta' from the Western Ghats is invariably smaller $(<1200 \mathrm{~mm}$ ), having a shorter rostrum and much brighter dorsal colour than those from the plains.

\section{Elapidae Boie, 1827}

\section{Calliophis nigrescens Günther, 1862}

Site 1: Two specimens, both presumably adults (SVL 567-601 mm, TL 648-689 mm), from under a small log in moist deciduous forest of Ayyanar koil at $600 \mathrm{~m}$, during February and another one from under, ground vegetation in cardamom plantations in Periya kavu at $850 \mathrm{~m}$.

Comments: Both snakes apparently belong to Smith's (1943) 'Variety II'. Although similar in scalation, these varieties Smith (1943) recognized are parapatric in distribution.

\section{Viperidae Oppel, 1811}

\section{Hypnale hypnale (Merrem, 1820)}

Site 1: Thirteen specimens from leaf litter (2), rocks (2), fallen logs (5) and buttresses (2) in moist deciduous forests of Ayyanar koil $(500 \mathrm{~m})$ and coffee plantations of Periya kavu (820 m).

Site 2: An adult from leaflitter in evergreen forest at $750 \mathrm{~m}$.

Comments: Our observation at 750 and $820 \mathrm{~m}$ (vs. $<600 \mathrm{~m}$ in Whitaker \& Captain, 2004), forms one of the highest elevation records for this species in India, barring the record of Kumar et al. (2001) from Andipparai at ca. $1100 \mathrm{~m}$, wherein they mentioned Hypnale hypnale to be syntopic with Trimeresurus malabaricus and T. macrolepis.

Trimeresurus macrolepis Beddome, 1862 (Fig. 26) Site 1: Sixteen specimens, from montane forests (7), tea (2), coffee (2), cardamom plantations (5) in High Wavys and Eravagalar estates between 1450-1650 m.

Comments: Two adult females were 950-960 mm long, thus forming the record length for this species (see Ganesh et al., 2008b).

\section{Trimeresurus malabaricus (Jerdon, 1854) (Fig. \\ 27)}

Site 1: Twenty specimens, of several colour morphs from Mudaliar ootru, Ayyanar koil, Periya kavu and Kottai malai Estates between $600-1200 \mathrm{~m}$ on fallen $\log (2)$, rock (11), branch (5), tree base (1) and leaf litter (1).

Site 2: Seventeen individuals from evergreen forests and tea plantations at elevations between 376-1018 $\mathrm{m}$ on overhanging branches close to streams (8), tea bushes (2), shrub, at a height of about $2 \mathrm{~m}$ (1), on the ground among leaf litter (1), on the buttress root of a tree (1), accumulated clump of twigs (2) and on rocks along streams (2).

Comments: Although Inger et al., (1984) recorded specimens from a hight as low as $110 \mathrm{~m}$ (Site 2), we did not observe any below $376 \mathrm{~m}$, despite our field surveys in lower elevations.

\section{Acknowledgements}

This work was carried out during our M.Sc. dissertation project. We thank the State Forest 
Departments of Kerala and Tamil Nadu for permission; Wildlife Association of Rajapalayam for funding our survey in Tamil Nadu and the estate administrators for providing food and accommodation. We thank S. Asokan and K. Tenmozhi, the project supervisors and other faculty members of the Zoology department of our college for their guidance. For providing access to their libraries, we thank the staff of Agumbe Rainforest Research Station, Chennai Snake Park and Madras Crocodile Bank. We are grateful to herpetologists Ashok Captain, Biju Sathyabama Das, David Gower, Gernot Vogel, Gerry Martin, K.V. Gururaja, P. Kannan, Kelum Manamendra-Arachchi, Madhava Meegaskumbura, Rohan Pethiyagoda, Romulus Whitaker and Ulrich Manthey for their suggestions, comments, references and guidance. We thank Harold Voris, Alan Resetar and Sarah Rieboldt (Field Museum of Natural History, Chicago) for kindly providing photographs of the paratype of Eutropis clivicola.

\section{Literature Cited}

Bauer, A. M., T. R. Jackmann, E. Greenbaum, A. de Silva, V. B. Giri and I. Das, 2010. Molecular evidence for taxonomic status of Hemidactylus brookii group taxa (Reptilia: Gekkonidae). Herpetological Journal, 20: 129-138.

Boulenger, G. A., 1894. Description of a new snake found in Travancore by Mr. S. Dighton. Pirmad. Journal of the Bombay Natural History Society, 8: 521.

Biju, S. D. and F. Bossuyt, 2005. Two new Philautus (Anura: Ranidae: Rhacophorinae) from Ponmudi Hill in the Western Ghats of India. Copeia, 2005: 29-37.

Biju, S. D. and F. Bossuyt, 2009. Systematics and phylogeny of Philautus Gistel, 1848 (Anura, Rhacophoridae) in the Western Ghats of India, with description of 12 new species. Zoological Journal of the Linnaean Society, 115: 374-444.

Biju, S. D. Y. Shouche, A. Dubois, S. K. Dutta and F. Bossuyt, 2010. A ground-dwelling rhacophorid frog from the highest mountain peak of the Western Ghats of India. Current Science, 98 (8): 1119-1125.

Carroll, R. L., 1988. Vertebrate paleontology and evolution. W.H. Freeman \& company, New York: 698.

Campbell, H. W. and S. P. Christman, 1982. Field techniques for herpetofaunal community analysis. In: Herpetological communities. Wildlife research report 13. U.S. Department of the interior and Fish and Wildlife service. Washington D.C.: 193-200.
Chandramouli, S. R., 2009a. Status and microhabitat preference of Otocryptis beddomii Boulenger, 1885 (Reptilia: Agamidae) in Ponmudi Hills, Western Ghats, Kerala, India. Taprobanica, 1 (2): 107-110.

Chandramouli, S. R., 2009b. An aberrant specimen of Calotes grandisquamis Günther, 1875 (Reptilia: Agamidae) with comments on its altitudinal distribution. Taprobanica, 1 (2): 111-114.

Daniels, R. J. R., 2005. Amphibians of Peninsular India. Univ. Press, Hyderabad, India: 268.

Das, I., 2002. A Photographic guide to Snakes and other Reptiles of India. New Holland Publishers, U.K: 144.

Dowling, H. G., 1951. A proposed standard system of counting ventrals in snakes. British Journal of Herpetology, 1: 97-99.

Dubois, A., 2004. The higher nomenclature of recent amphibians. Alytes, 22 (1-2): 1-14.

Dubois, A. and R. Bour, 2010. The nomenclatural status of the nomina of amphibians and reptiles created by Garsault (1764), with a parsimonious solution to an old nomenclatural problem regarding the genus Bufo (Amphibia, Anura), comments on the taxonomy of this genus, and comments on some nomina created by Laurenti (1768). Zootaxa, 2447: 1-52.

Dutta, S. K., 1997. The Amphibians of India and Sri Lanka; Checklist and Bibliography. Odyssey Publishing House, Orissa, India: 342.

Dutta, S. K. and K. Manamendra-Arachchi., 1996. The Amphibian Fauna of Sri Lanka. Wildlife Heritage Trust of Sri Lanka, Colombo, Sri Lanka: 230.

Ferguson, S. H., 1895. List of snakes taken in Travancore from 1888 to 1895. Journal of the Bombay Natural History Society, 10: 68-77.

Ferguson, S. H., 1904. A list of Travancore batrachians. Journal of the Bombay Natural History Society, 15: 499-509.

Ganesh, S. R., S. Asokan and P. Kannan, 2008a. A preliminary survey of amphibians and reptiles in Cardamom Hills, Western Ghats, Tamil Nadu. Cobra, 2 (2):1-9.

Ganesh, S. R., S. Asokan and P. Kannan, 2008b. Record length of large-scaled pit viper (Trimeresurus macrolepis) Beddome, 1862; with notes on its conservational significance. Cobra, 2 (3):17-22.

Ganesh, S. R., S. Asokan and P. Kannan, 2009. Record of Oligodon travancoricus Beddome, 1877 
(Serpentes: Colubridae) from Grizzled Squirrel Sanctuary, Western Ghats, Tamil Nadu, India. The Herpetological Bulletin, 109: 25-28.

Gosner, L. K., 1960. A simplified table for staging anuran embryos and larvae with notes on identification. Herpetologica, 16 (3):183-190.

Gower, D. J. and J. D. Ablett, 2006. Counting ventral scales in anilioid snakes. Herpetological Journal, 16: 259-263.

Gower, D. J. and J. D. Winkler, 2007. Taxonomy of the Indian snake Xylophis Beddome (Serpentes: Caenophidia), with description of a new species. Hamadryad, 31 (2): 315-329.

Hutton, A. F., 1949. Notes on the snakes and mammals of the High Wavy Mountains, Madura district, South India. Part I Snakes. Journal of the Bombay Natural History Society, 48 (3): 454-460.

Hutton, A. F. and P. David, "2008” 2009. Notes on a collection of snakes from south India, with emphasis on the snake fauna of Meghamalai Hills (High Wavy Mountains). Journal of the Bombay Natural History Scoiety, 105 (3): 299-316.

Inger, R. F., H. B. Shaffer, M. Koshy and R. Bakde, 1984. A report on a collection of amphibians and reptiles from the Ponmudi, Kerala, South India. Journal of the Bombay Natural History Society, 81 (2): 406-427 \& 551-570.

Ishwar, N. M., R. Chellam and A. Kumar, 2001. Distribution of forest floor reptiles in the rainforest of Kalakkad-Mundanthurai Tiger Reserve, South India. Current Science, 80 (3): 413-418.

Kumar, A., R. Chellam, B. Choudary, D. Mudappa, K. Vasudevan, N. M. Ishwar and B. R. Noon, 2001. Impact of rainforest fragmentation on small mammals and herpetofauna in the Western Ghats, South India. Report of Wildlife Institute of India, Sálim Ali Centre for Ornithology and Natural History and U.S. Fish and Wildlife Service: 28.

Kuramoto, M., S. H. Joshy, A. Kurabayashi and M. Sumida, 2007. The Genus Fejervarya (Anura: Ranidae) in Central Western Ghats, India, with descriptions of four new cryptic species. Current Herpetology, 26 (2): 81-105.

Malhotra, A. and K. Davis, 1991. A report on the herpetological survey of the Srivilliputhur Reserve Forests, Tamil Nadu. Journal of the Bombay Natural History Society, 88 (2): 157-166.

Manamendra-Arachchi, K. and R. Pethiagoda, 2005. The Sri Lankan shrub-frogs of the genus Philautus
Gistel, 1848 (Ranidae: Rhacophorinae), with description of 27 new species. The Raffles Bulletin of Zoology, Supplement No. 12: 163-303.

Molur, S. and S. Walker. (Eds). 1998. Reptiles of India Report summary, CAMP workshop. Zoos' Print, 13 (7): 226.

Myers, N., R. A. Mittermeier, C. G. Mittermeier, G. A. B. da Fonseca and J. Kent, 2000. Biodiversity hotspots for conservation priorities. Nature, 403: 853-858.

Satyamurti, S. T., 1967. The South Indian Amphibia in the collection of the Madras Government Museum. Director of Stationary \& Printing, Madras: 90.

Sharma, R. C., 2003. Handbook - Indian Snakes. Director-Zoological Survey of India, Kolkata: 292.

Smith, M. A., 1935. Fauna of British India including Ceylon and Burma. Vol - II Sauria. Taylor \& Francis, London: 440.

Smith, M. A., 1943. Fauna of British India including Ceylon and Burma. Vol - III Serpentes. Taylor \& Francis, London: 583.

Thomas, J. and P. Easa, 1997. Reptile fauna of Peechi-Vazhani Wildlife Sanctuary. Cobra, 29: 14-18.

Vasudevan, K., A. Kumar and R. Chellam, 2001. Structure and composition of rainforest floor amphibian communities in Kalakkad-Mundanthurai Tiger Reserve. Current Science, 80 (3): 406-412.

Vogel, G. and P. David, 2006. On the taxonomy of the Xenochrophis piscator complex (Serpentes, Natricidae). Proceedings of the $13^{\text {th }}$ congress of the Societas Europea Herpetologica: 241-246.

Wall, F., 1914. Are the snakes Oligodon travancoricus (Beddome) and Oligodon venustus (Jerdon) entitled to specific distinction? Journal of the Bombay Natural History Society, 23: 169-170.

Wall, F., 1919. Notes on a collection of snakes made in the Nilgiri Hills and the adjacent Wynaad. Journal of the Bombay Natural History Society, 26: 552-584.

Wall, F., 1920. Notes on a collection of snakes from Shenbaganur, Palni Hills. Journal of the Bombay Natural History Society, 29: 388-398.

Whitaker, R., 1978. Common Indian snakes - a field guide. MacMillan Press, New Delhi: 154.

Whitaker, R. and A. Captain. 2004. Snakes of India The field guide. Draco Books, Chengelpet, South India: 481. 
Appendix 1: Presence-absence matrix of sightings of species reported earlier and present in the same site: + = presence; - = absence; ++ = presence after subsequent treatment; -- = absence after subsequent treatment; $*$ = only Serpentes were sampled; N.A = not applicable.

\section{Species}

Ichthyophis beddomei Peters, 1879

Gegeneophis carnosus (Beddome, 1870)

Bufo melanostictus (Schneider, 1799)

B. microtympanum (Boulenger, 1882)

B. parietalis (Boulenger, 1882)

B. beddomei (Günther, 1876)

Pedostibes tuberculosus Günther, 1876

Ramanella triangularis (Günther, 1876)

Ramanella sp.

Raorchestes anili (Biju \& Bossuyt, 2006)

R. akroparallagi (Biju \& Bossuyt, 2009)

R. beddomei (Günther, 1876)

$R$. cf. bobingeri

$R$. charius (Rao, 1937)

R. ponmudi (Biju \& Bossuyt, 2005)

$R$. signatus (Boulenger, 1882)

$R$. cf. travancoricus

Pseudophilautus variabilis (Günther, 1859)

P. temporalis (Günther, 1864)

P. femoralis(Günther, 1864)

Philautus s. lat. sp. 1

Philautus s. lat. sp. 2

Rhacophorus malabaricus Jerdon, 1870

Micrixalus fuscus (Boulenger, 1882)

M. nudis Pillai, 1978

Fejervarya keralensis (Dubois, 1980)

$F$. cf. limnocharis

Sylvirana aurantiaca (Boulenger, 1904)

S. temporalis (Günther, 1864)

Hydrophylax malabarica (Tschudi, 1838)

Indirana beddomei (Günther, 1876)

I. brachytarsus (Günther, 1876)

I. semipalmatus (Boulenger, 1882)

I. diplosticta (Günther, 1876)

I. cf. diplostictus

I. leptodactylus(Boulenger, 1882)

Nyctibatrachus major Boulenger, 1882

$N$. beddomei (Boulenger, 1882)

N. aliciae Inger, Shaffer, Koshy \& Bakde, 1984

Nyctibatrachus sp. A

Nyctibatrachus sp. B

Cnemaspis ornata (Beddome, 1870)

C. beddomei (Theobald, 1876)

C. nairi Inger, Marx \& Koshy, 1984

C. tropidogaster (Boulenger, 1885)

C. littoralis (Jerdon, 1853)

C. kandiana (Boulenger, 1885)

Cnemaspis sp.

Hemidactylus frenatus Schlegel, 1836

H. parvimaculatus Deraniyagala, 1953

H. anamallensis (Günther, 1875)

H. maculatus (Dumèril \& Bibron, 1836)

Gehyra mutilata (Weigman, 1835)

Otocryptis beddomii Boulenger, 1885

Calotes calotes (Linnaeus, 1758)

C. versicolor (Daudin, 1802)

C. elliotii Günther, 1864

C. grandisquamis Günther, 1875

Draco dussumieri Dumèril \& Bibron, 1837

\begin{tabular}{|c|c|c|c|c|}
\hline Site 1 & $\begin{array}{l}\text { Hutton } \\
\text { (1949)* }\end{array}$ & $\begin{array}{l}\text { Malhotra \& } \\
\text { Davis (1991) }\end{array}$ & Site 2 & $\begin{array}{l}\text { Inger et al. } \\
\quad(1984)\end{array}$ \\
\hline- & N.A & - & + & + \\
\hline- & N.A & - & - & + \\
\hline+ & N.A & + & - & + \\
\hline+ & N.A & - & - & - \\
\hline+ & N.A & - & + & + \\
\hline- & N.A & - & - & + \\
\hline- & N.A & - & - & + \\
\hline- & N.A & + & - & + \\
\hline+ & N.A & - & - & - \\
\hline- & N.A & - & + & ++ \\
\hline- & N.A & - & + & ++ \\
\hline+ & N.A & - & - & - \\
\hline+ & N.A & - & - & ++ \\
\hline+ & N.A & - & - & -- \\
\hline+ & N.A & - & - & - \\
\hline- & N.A & - & - & + \\
\hline+ & N.A & - & - & - \\
\hline- & N.A & - & - & -- \\
\hline- & N.A & - & - & -- \\
\hline- & N.A & - & - & -- \\
\hline- & N.A & - & + & - \\
\hline- & N.A & - & + & - \\
\hline- & N.A & - & + & + \\
\hline+ & N.A & + & + & + \\
\hline- & N.A & - & + & + \\
\hline+ & N.A & - & + & + \\
\hline+ & N.A & - & - & - \\
\hline- & N.A & - & + & + \\
\hline+ & N.A & + & + & + \\
\hline+ & N.A & - & - & - \\
\hline+ & N.A & + & + & + \\
\hline- & N.A & - & + & + \\
\hline+ & N.A & - & - & + \\
\hline- & N.A & - & - & + \\
\hline+ & N.A & - & - & - \\
\hline+ & N.A & - & - & - \\
\hline+ & N.A & + & + & + \\
\hline- & N.A & + & - & + \\
\hline- & N.A & - & - & + \\
\hline- & N.A & - & - & + \\
\hline- & N.A & - & - & + \\
\hline+ & N.A & - & + & + \\
\hline+ & N.A & - & - & - \\
\hline+ & N.A & - & - & + \\
\hline- & N.A & - & - & -- \\
\hline- & N.A & - & - & + \\
\hline- & N.A & -- & - & - \\
\hline+ & N.A & - & + & - \\
\hline+ & N.A & - & + & + \\
\hline- & N.A & - & ++ & - \\
\hline+ & N.A & + & - & - \\
\hline+ & N.A & + & - & - \\
\hline- & N.A & - & + & - \\
\hline- & N.A & - & + & + \\
\hline+ & N.A & - & + & - \\
\hline- & N.A & + & - & + \\
\hline+ & N.A & - & + & ++ \\
\hline+ & N.A & + & + & - \\
\hline+ & N.A & + & + & + \\
\hline
\end{tabular}


Psammophilus dorsalis(Gray, 1831)

P. blanfordanus(Stoliczka, 1871)

Eutropis macularia (Blyth, 1853)

E. carinata (Schneider, 1801)

E. clivicola (Inger, Shaffer, Koshy \& Bakde, 1984)

E. cf. beddomei

Kaestlea laterimaculata (Boulenger, 1887)

K. travancorica (Beddome, 1870)

Ristella guentheri Boulenger, 1887

R. beddomei Boulenger, 1887

$R$ travancorica (Beddome, 1870)

Sphenomorphus dussumieri (Dumèril \& Bibron, 1839)

Varanus bengalensis (Daudin, 1802)

Typhlops beddomi Boulenger, 1890

Ramphotyphlops braminus(Daudin, 1803)

Melanophidium punctatum Beddome, 1871

Melanophidium sp.

Plectrusrus perroteti (Dumèril, Bibron \& Dumèril 1854)

Uropeltis ceylanica Cuvier, 1829

U. woodmasoni (Theobald, 1876)

U. elliotti (Gray, 1858)

U. pulneyensis (Beddome, 1863)

Uropeltis arcticeps madurensis (Beddome, 1878)

$U$. cf. dindigalensis

Rhinophis sanguineus Beddome, 1863

R. travancoricus Boulenger, 1892

Pythomn molurus (Linnaeus, 1758)

Coelognathus helena monticollaris Schultz, 1992

Ptyas mucosa (Linnaeus, 1758)

Argyrogena fasciolatus (Shaw, 1802)

Oligodon affinis Günther, 1862

O. travancoricus Beddome, 1887

O. venustus (Jerdon, 1853)

O. brevicaudus Günther, 1862

O. taeniolatus (Jerdon, 1853)

Lycodon travancoricus (Beddome, 1870)

L. striatus (Shaw, 1802)

Dryocalamus nympha (Daudin, 1803)

Dendrelaphis grandoculis (Boulenger, 1890)

D. bifrenalis (Boulenger, 1890)

Xenochrophis piscator (Schneider, 1799)

Amphiesma beddomei (Günther, 1864)

A. stolata (Linnaeus, 1758)

Macropisthodon plumbicolor (Cantor, 1839)

Atritium schistosum (Daudin, 1803)

Xylophis captaini Gower \& Winkler, 2007

Boiga ceylonensis (Günther, 1858)

B. nuchalis (Günther,1875)

B. dightoni (Boulenger, 1894)

Ahaetulla dispar (Günther, 1864)

A. perroteti (Dumèril, Bibron \& Dumèril 1854)

A. nasuta (Lacépède, 1789)

A. pulverulentua (Dumèril, Bibron \& Dumèril 1854)

Calliophis nigrescens Günther, 1862

Naja naja (Linnaeus, 1758)

Ophiophagus hannah (Cantor, 1839)

Daboia russelii (Shaw \& Nodder, 1797)

Hypnale hypnale (Merrem, 1820)

Trimeresurus macrolepis Beddome, 1862

T. malabaricus (Jerdon, 1854)

T. gramineus (Shaw, 1802)

Tropidolaemus huttoni (Smith, 1949) 


\section{PLATE 01}

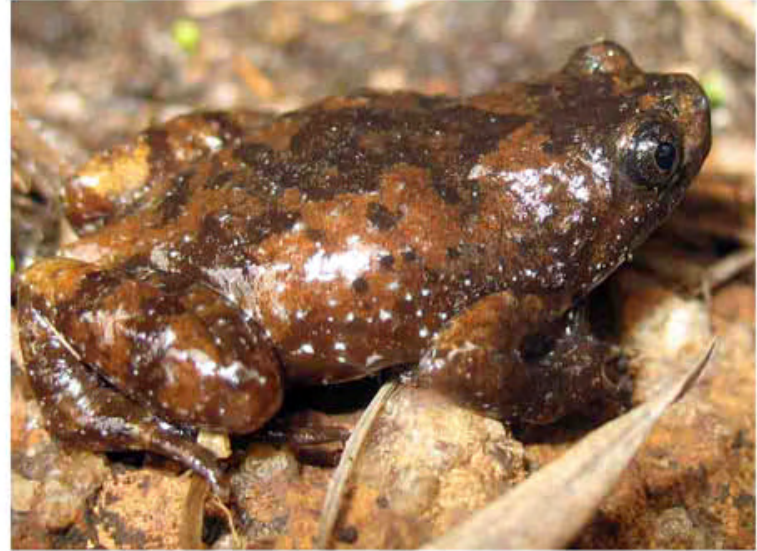

Fig. 01: Ramanella sp.

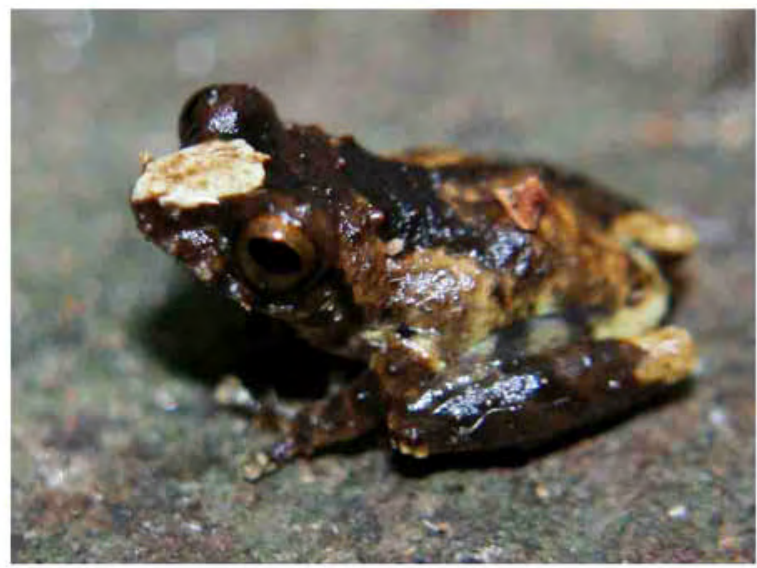

Fig. 03: Raorchestes anili

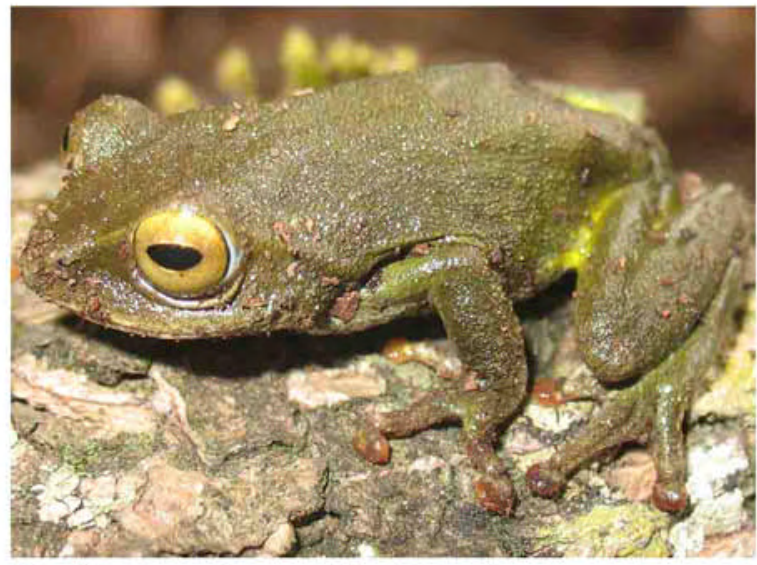

Fig. 05: Raorchestes cf. bobingeri

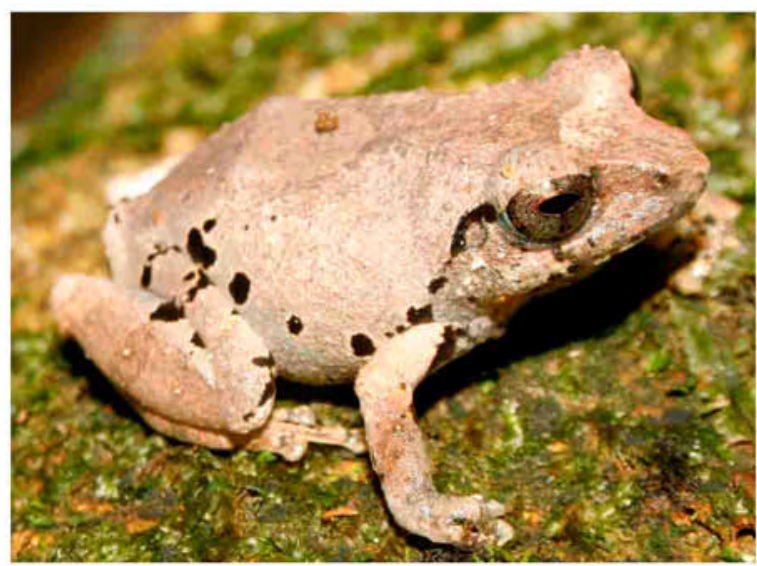

Fig. 07: Philautus sensu lato sp. 1

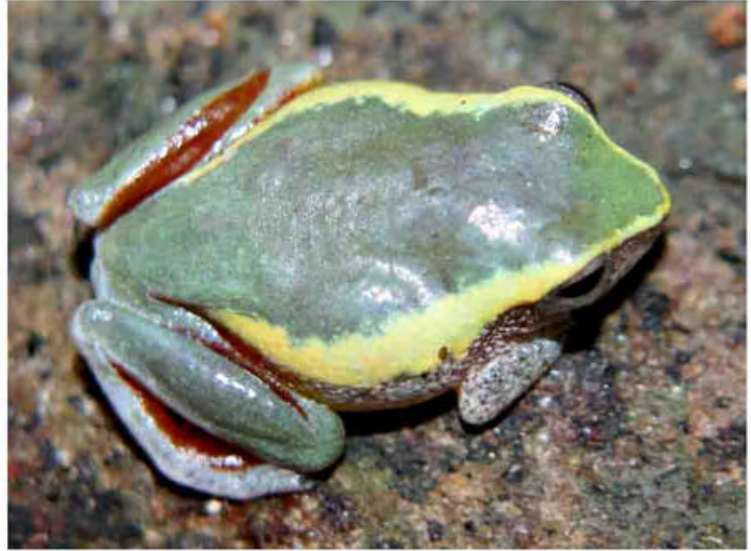

Fig. 02: Raorchestes akroparallagi

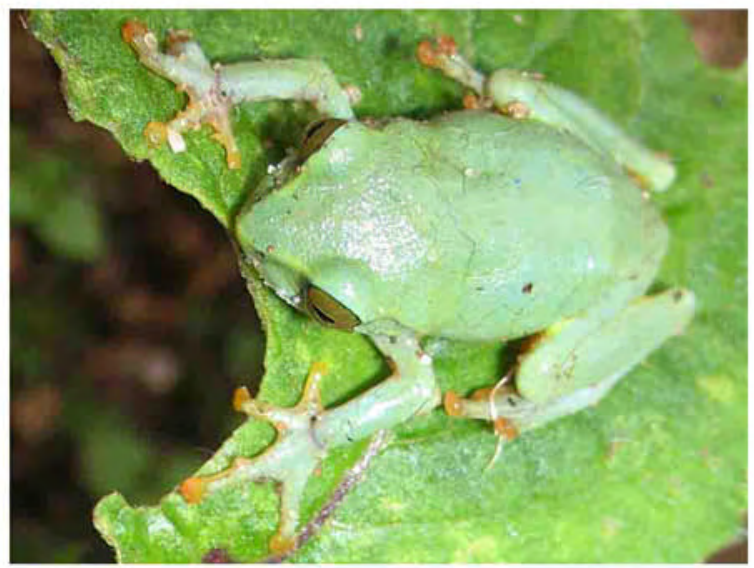

Fig 04: Raorchestes beddomii

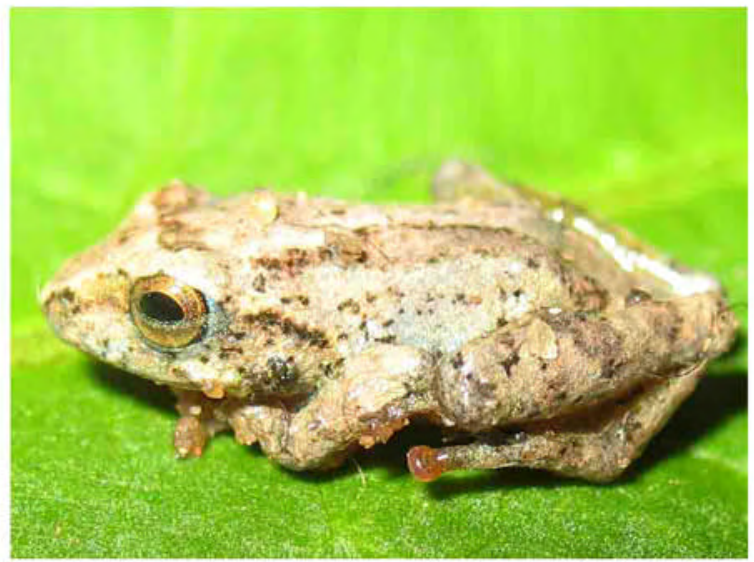

Fig. 06: Raorchestes cf. travancoricus

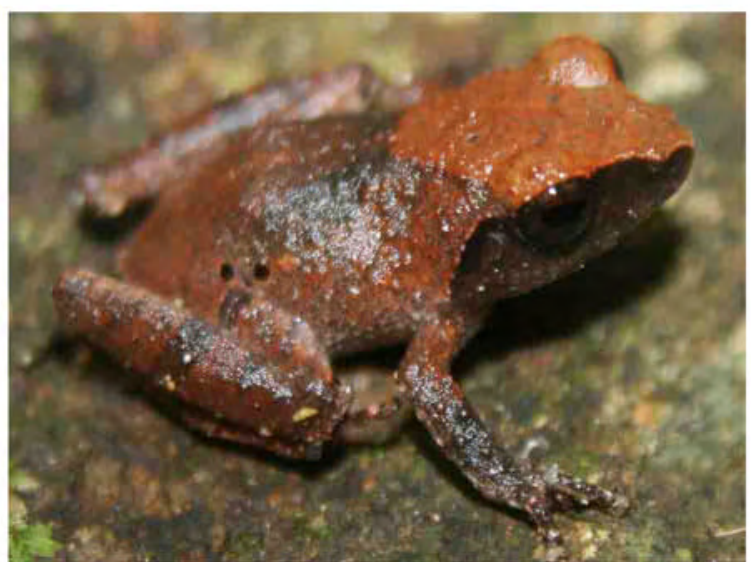

Fig. 08: Philautus sensu lato sp. 2 


\section{PLATE 02}

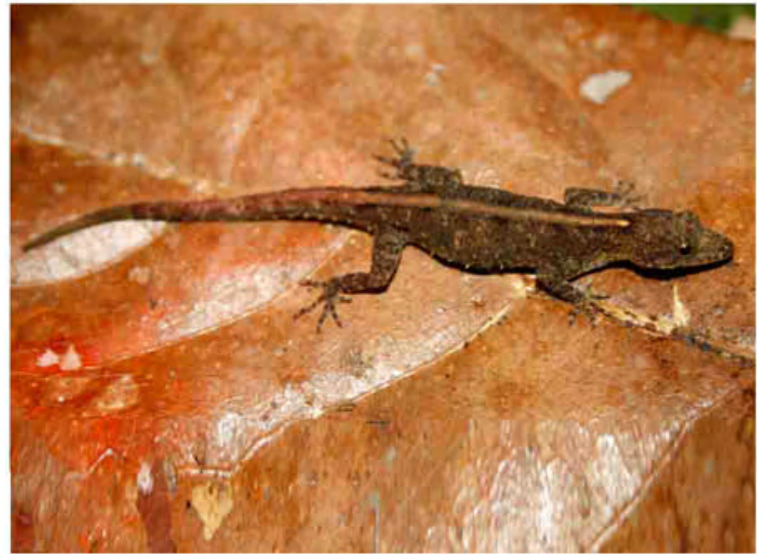

Fig. 9: Cnemaspis sp.

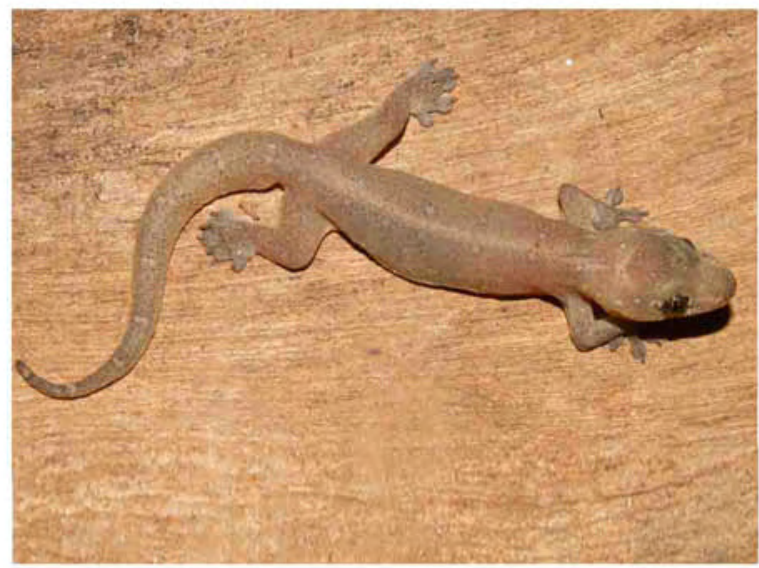

Fig. 11: Gehyra mutilata

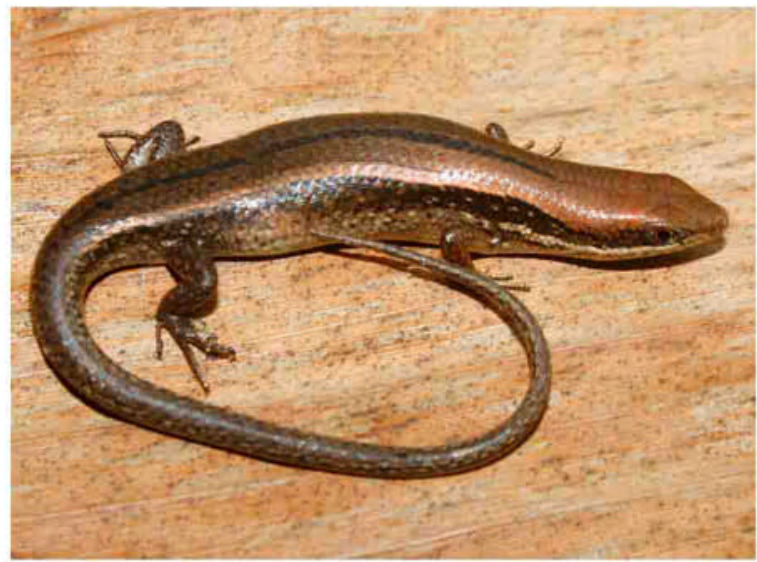

Fig. 13a: Eutropis clivicola

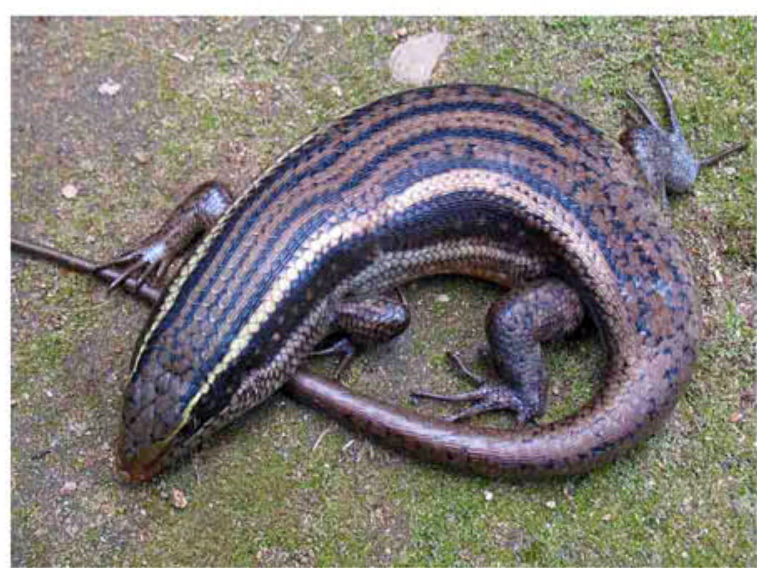

Fig. 14: Eutropis cf. beddomei

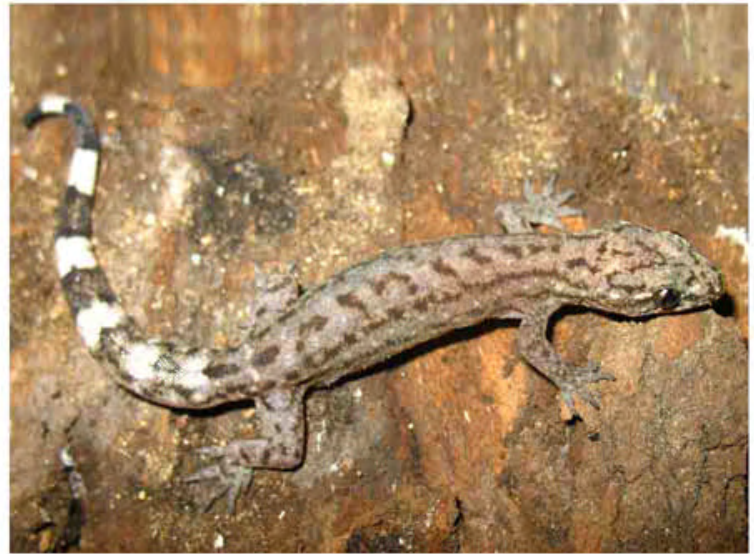

Fig. 10: Hemidactylus anamallensis

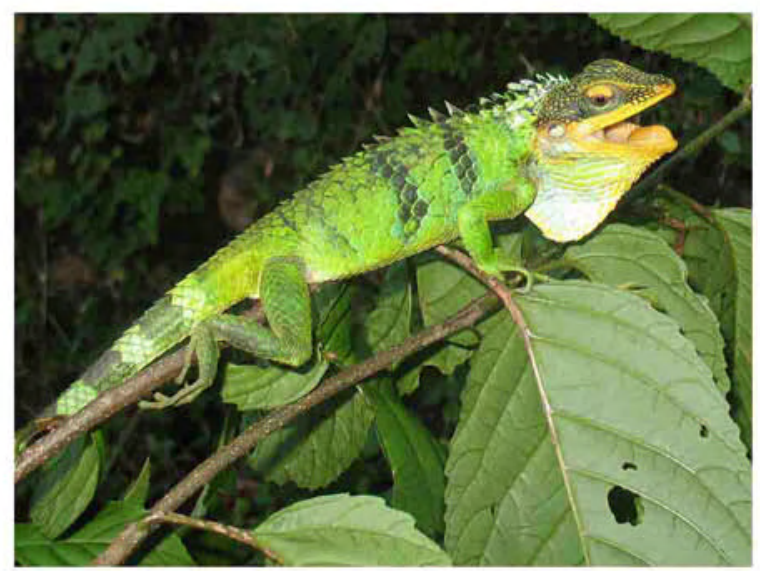

Fig 12: Calotes grandisquamis

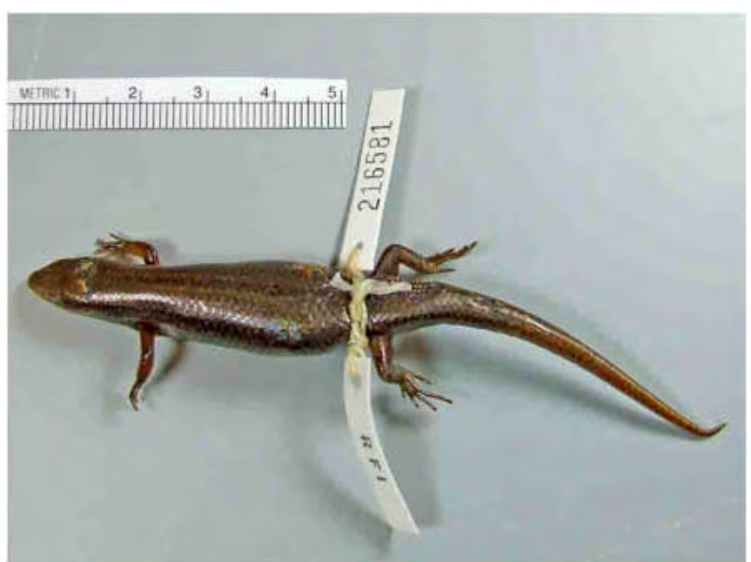

Fig. 13b: Paratype of Eutropis clivicola - FMNH 216581

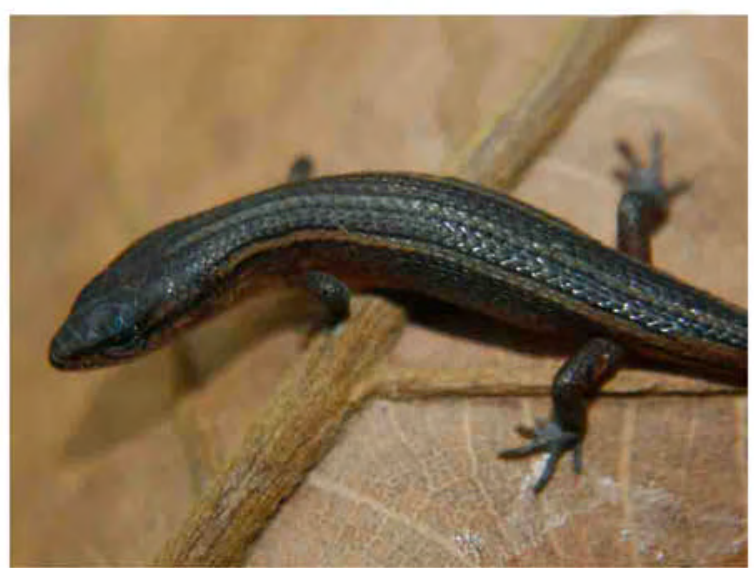

Fig. 15: Ristella guentheri 


\section{PLATE 03}

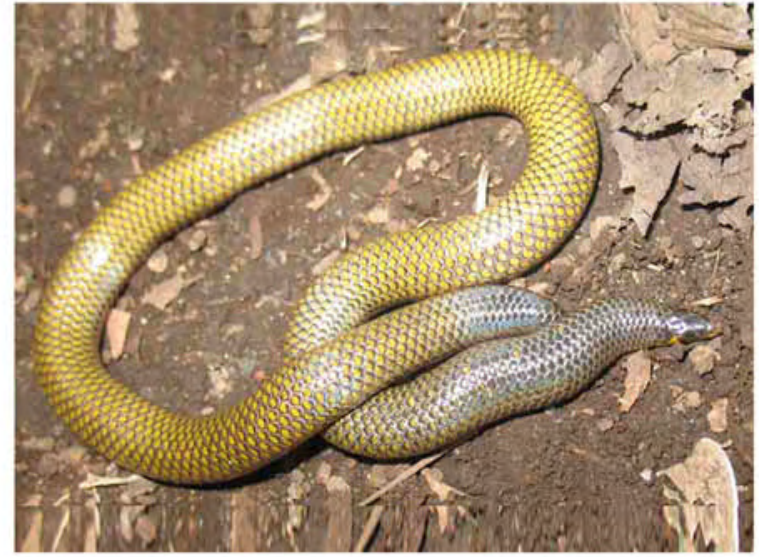

Fig. 16: Uropeltis cf. dindigalensis

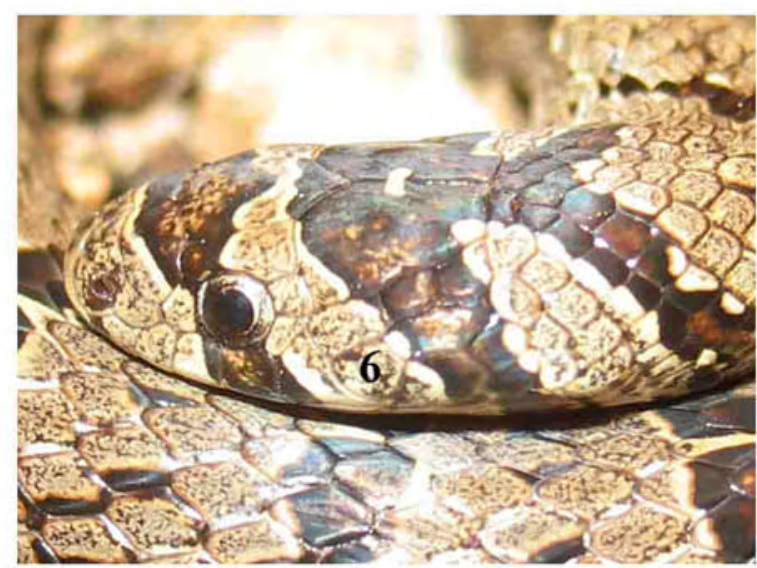

Fig. 17b: Oligodon venustus - head

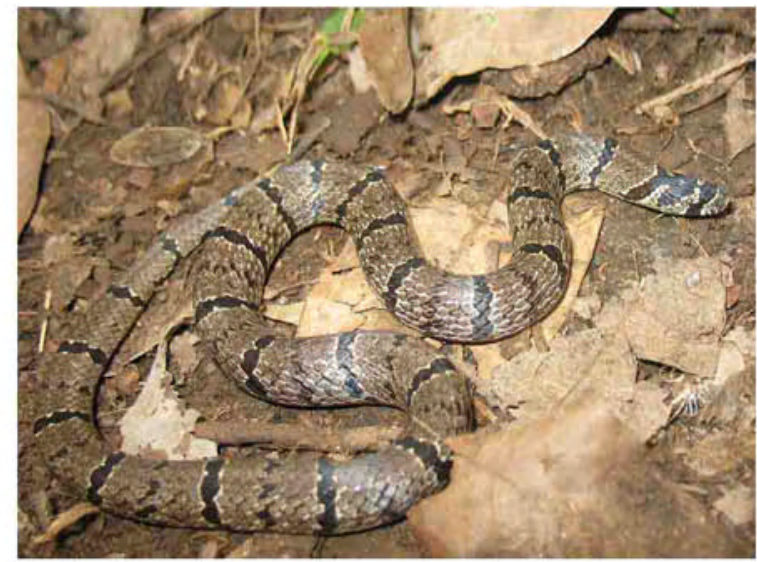

Fig. 18a: Oligodon travancoricus

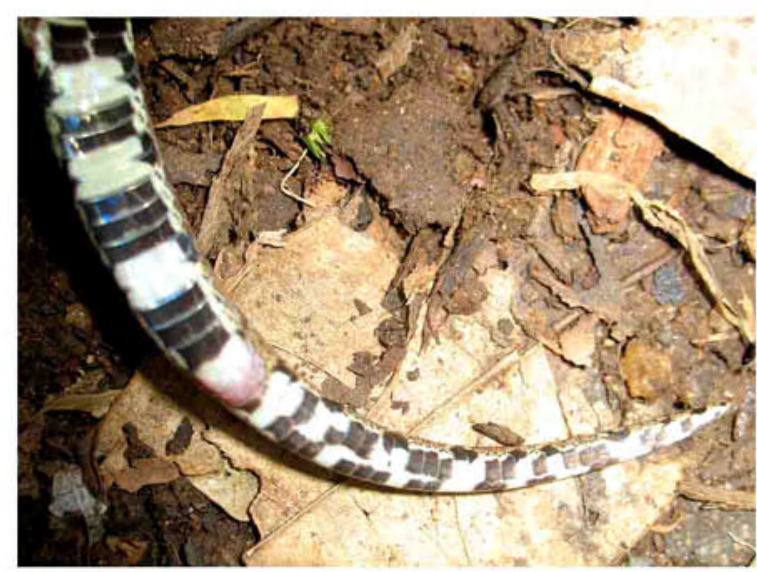

Fig. 18c: Oligodon travancoricus - subcaudals

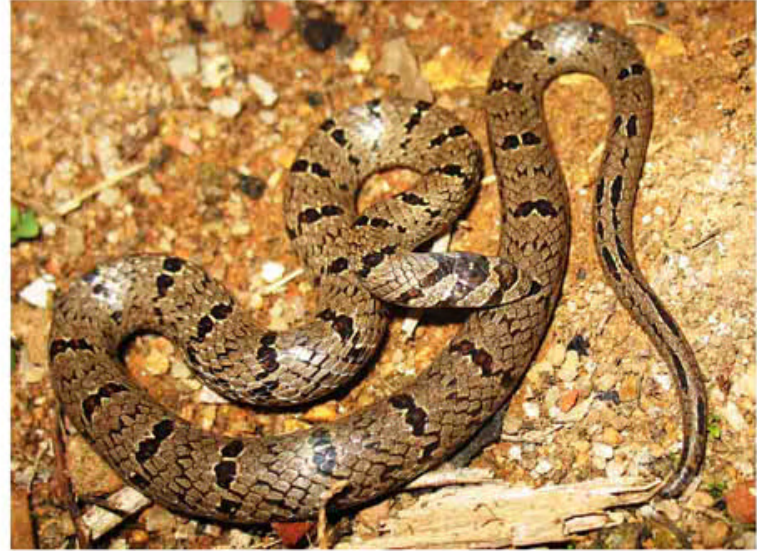

Fig. 17a: Oligodon venustus

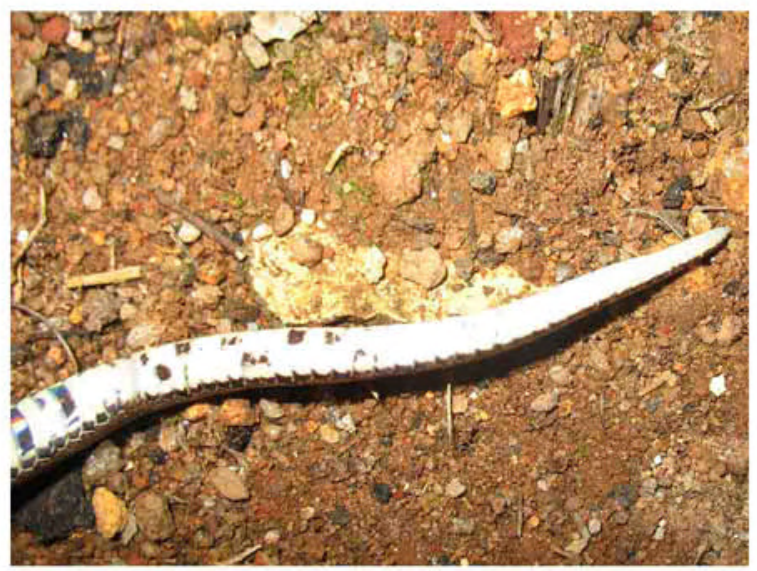

Fig 17c: Oligodon venustus - subcaudals

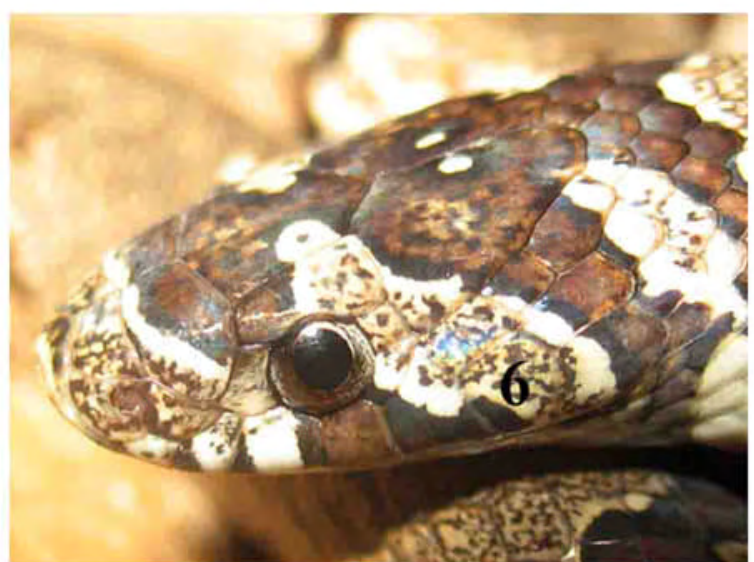

Fig. 18b: Oligodon travancoricus - head

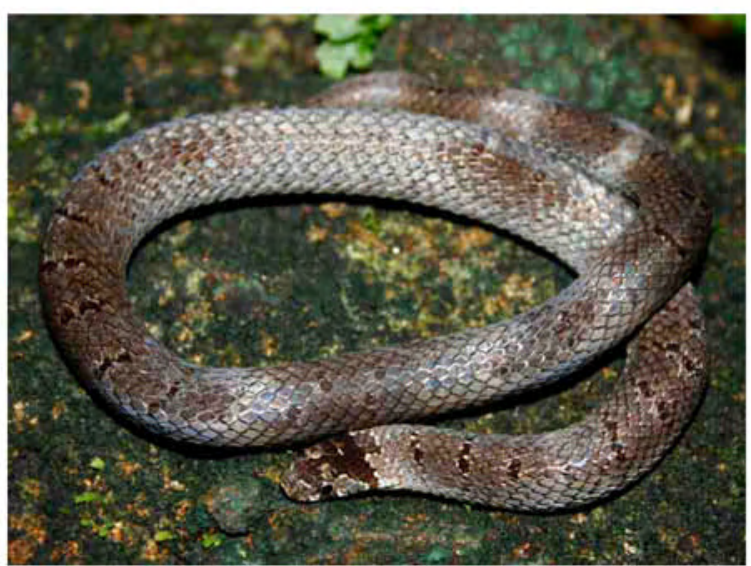

Fig. 19: Oligodon affinis 


\section{PLATE 04}

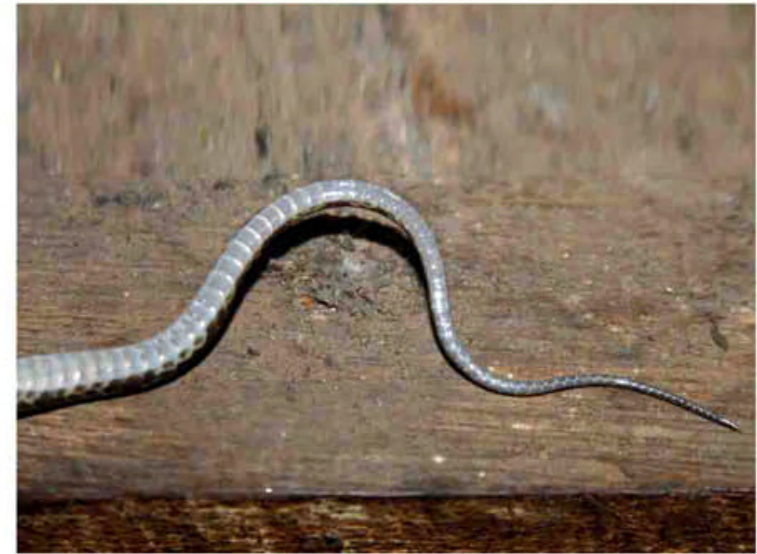

Fig. 20: Lycodon travancoricus - subcaudals

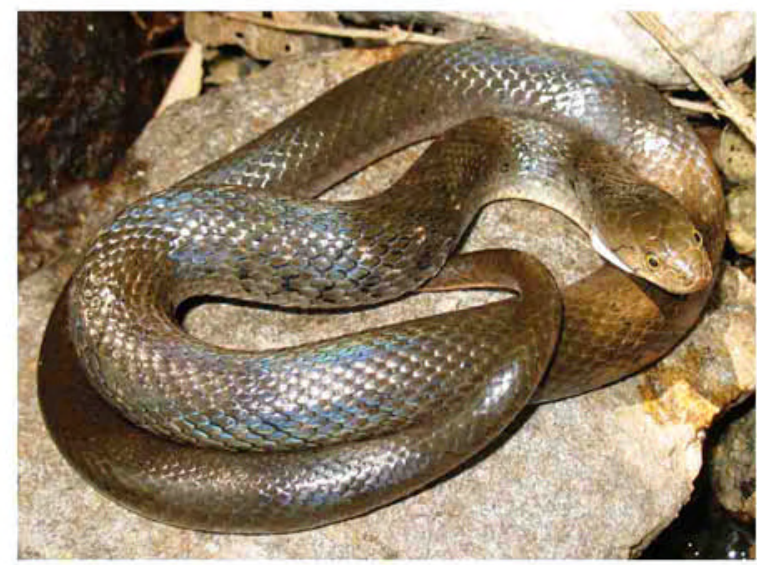

Fig. 22: Xenochrophis piscator

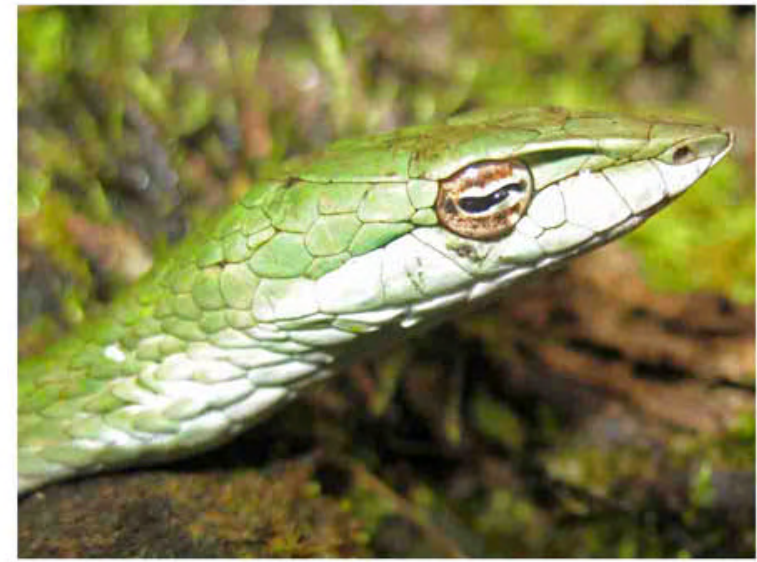

Fig. 24: Ahaetulla dispar

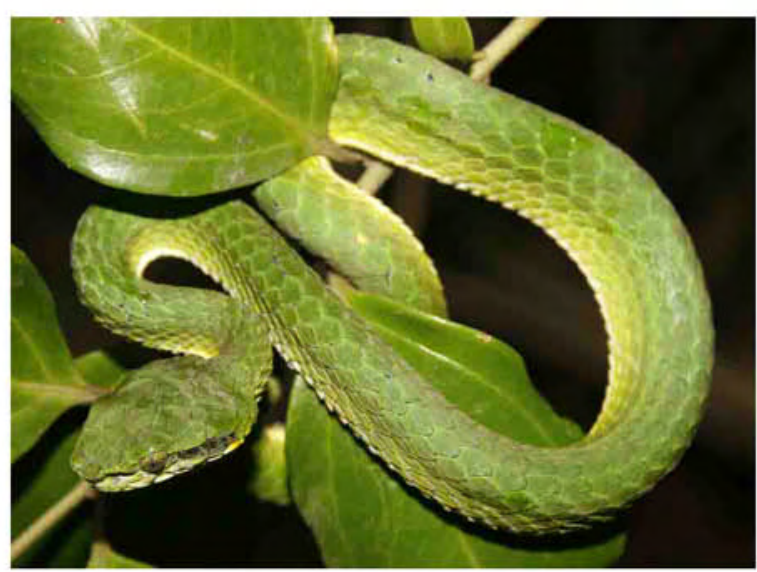

Fig. 26: Trimeresurus macrolepis

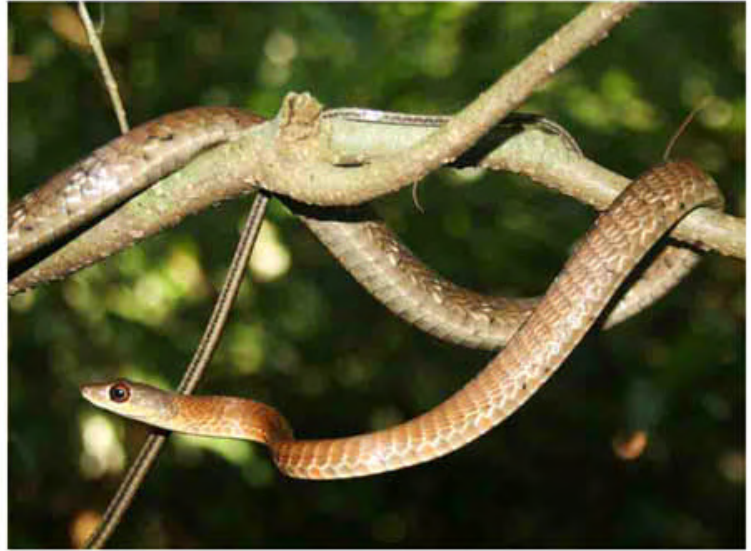

Fig. 21: Dendrelaphis grandoculis

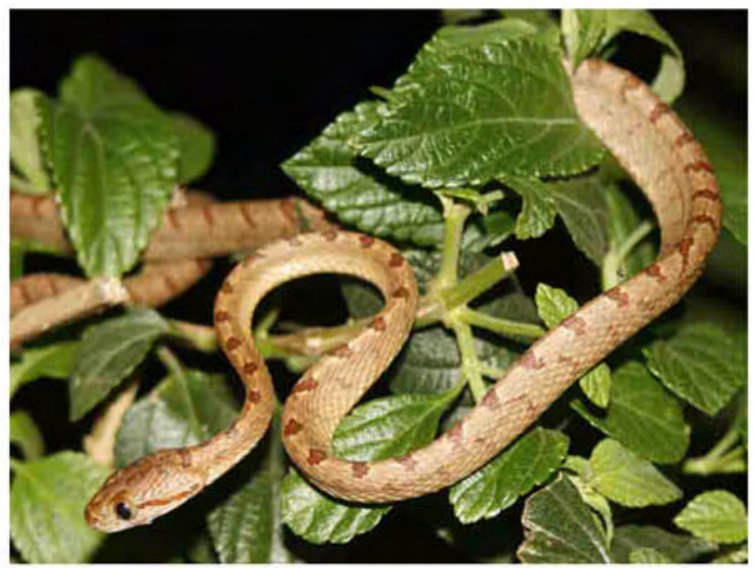

Fig 23: Boiga muchalis

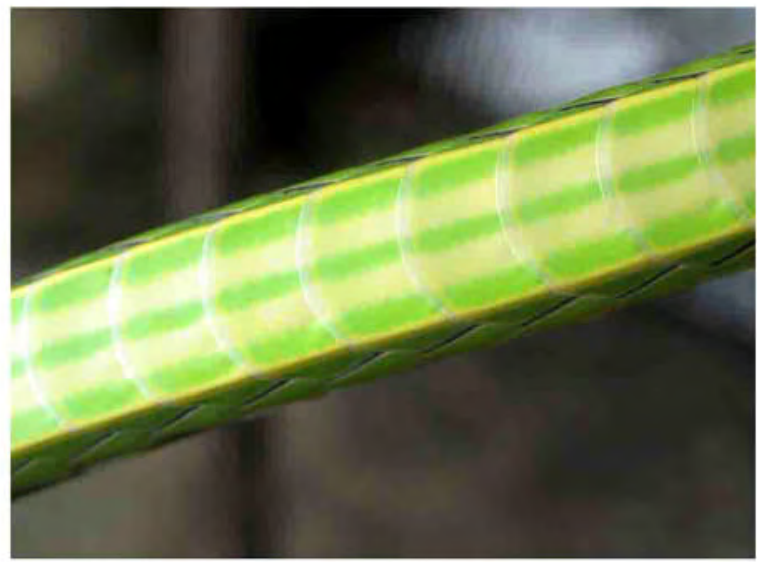

Fig. 25: Ahaetulla nasuta - Ventral

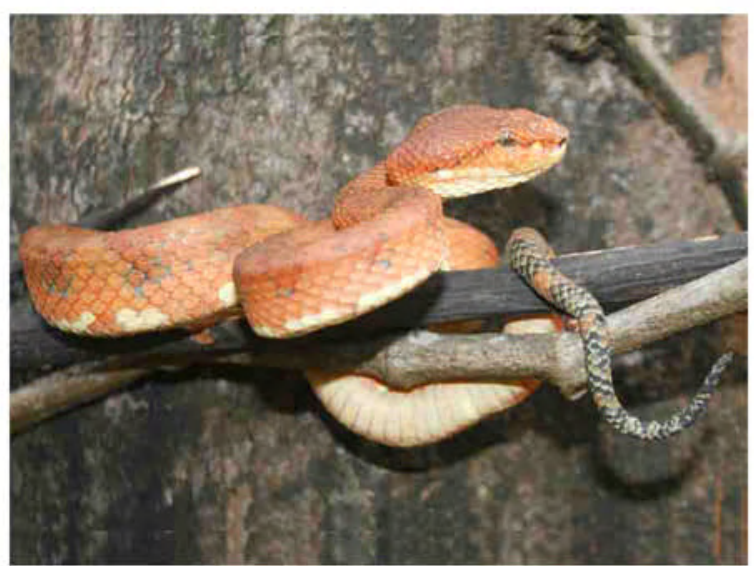

Fig. 27: Trimeresurus malabaricus 